\title{
Characterization and taxonomic key for tadpoles (Amphibia: Anura) from the northwestern region of São Paulo State, Brazil ${ }^{1}$
}

\author{
Denise de Cerqueira Rossa-Feres ${ }^{2}$ \& Fausto Nomura ${ }^{3,4}$
}

Biota Neotropica v6 (n1) - http://www.biotaneotropica.org.br/v6n1/pt/abstract?identification-key+bn00706012006

\author{
Date Received 05/15/2005 \\ Revised 10/10/2005 \\ Accepted 01/01/2006
}

\begin{abstract}
${ }^{1}$ This work was supported by the state of São Paulo Research Foundation (FAPESP), within the BIOTA/FAPESP -
The Biodiversity Virtual Institute Program (http://www.biota.org.br; grant 01/13341-3)

${ }^{2}$ Departamento de Zoologia e Botânica. Universidade Estadual Paulista-UNESP, R. Cristóvão Colombo, n 2265, Jd Nazareth, 15054-000 São José do Rio Preto, São Paulo State, Brazil. e-mail: denise@ibilce.unesp.br (corresponding author)

${ }^{3}$ Laboratório de Ecologia Animal. Universidade Estadual Paulista-UNESP/São José do Rio Preto, São Paulo State, Brazil. e-mail: fausto_nomura@yahoo.com.br

${ }^{4}$ Programa de Pós-Graduação em Zoologia. Universidade Estadual Paulista-UNESP/Rio Claro, São Paulo State, Brazil.
\end{abstract}

\begin{abstract}
Rossa-Feres, D.C and Nomura,F. Characterization and taxonomic key for tadpoles (Amphibia: Anura) from the northwestern region of São Paulo State, Brazil. Biota Neotrop. Jul/Dez 2005, vol. 5, no. 2 http://www.biotaneotropica.org.br/ v6n1/pt/abstract?identification-key+bn00706012006. ISSN 1676-0611

Difficulties in species identification and the absence of taxonomic keys are several of the obstacles in elaborating adequate conservation, management and habitat recovery programs. This study provides a taxonomic key, morphological characterization, and drawings for the 22 known anuran tadpoles from the northwestern region of São Paulo state, southeastern Brazil. Specimens of all species analyzed are deposited in the scientific amphibian collection of Universidade Estadual Paulista (DZSJRP), São José do Rio Preto, SP.
\end{abstract}

Key words: Cerrado, Neotropical region, biodiversity, morphological variation, taxonomy.

\section{Resumo}

Rossa-Feres, D.C and Nomura,F. Caracterização e chave taxonômica para girinos (Amphibia: Anura) da região noroeste do estado de São Paulo, Brasil. Biota Neotrop. Jul/Dez 2005, vol. 5, no. 2 http://www.biotaneotropica.org.br/v6n1/pt/ abstract?identification-key+bn00706012006. ISSN 1676-0611

Dificuldades na identificação de espécies e a ausência de chaves taxonômicas são alguns dos maiores obstáculos na elaboração de programas de conservação, manejo e recuperação de hábitats. Este estudo apresenta uma chave taxonômica, caracterização morfológica e desenhos para as 22 espécies de larvas de anuros conhecidas para a região noroeste do Estado de São Paulo, sudeste do Brasil. Espécimes de todos os girinos analisados estão depositados na coleção científica da Universidade Estadual Paulista, São José do Rio Preto, SP (DZSJRP).

Palavras-chave: Cerrado, região neotropical, biodiversidade, variação morfológica, taxonomia. 


\section{Introduction}

For the majority of anuran species, tadpoles are the easiest developmental stage to encounter and to collect, remaining in ponds for longer periods of time than adults (Lips \& Savage 1996, Altig \& McDiarmid 1999a). However, difficulties in tadpole identification are a major obstacle in anuran surveys, and in the development of conservation and biodiversity management programs. As a consequence, identification keys are valuable tools, especially where the anurofauna is poorly known, as is the case for the Brazilian inland regions (Haddad \& Sazima 1992, Brandão \& Araújo 1998, Haddad 1998). Despite the intensive use of land for agriculture and pasture activities (PROBIO 1998), 29 species of anurans have been registered in the Northwestern region of São Paulo State (Vizotto 1967, Cais 1992, Bernarde \& Kokubum 1999, Rossa-Feres \& Jim 2001). The climate of this region is AW type, with a rainy season (October to March) and a pronounced dry season (April to September) that receive only $15 \%$ of the total annual precipitation, which ranges from 1100 to $1500 \mathrm{~mm}$ (Barcha \& Arid 1971). The climate and human activities have restricted the environment available for the development of tadpoles mostly to temporary ponds, with annual variations in the hydroperiod (Rossa-Feres \& Jim 2001). In this report, we provide a morphological characterization and taxonomic key for tadpoles of 22 species for which the larval stages are known

\section{Material and Methods}

For the elaboration of the taxonomic key we examined tadpoles between stages 34 and 40 (sensu Gosner 1960) deposited in the scientific amphibian collection (DZJSRP) of Universidade Estadual Paulista, UNESP, São José do Rio Preto campus, SP. The characters are described according to Altig \& McDiarmid (1999b), with coloration analysis based on preserved specimens, and the classification according Frost (2004), Faivovich et al. (2005) and Nascimento et al. (2005). In the item Characteristics, total length of each tadpole is given with mean \pm standard deviation (range). Drawings were made under a camera lucida adapted to a Zeiss stereomicroscope and images were captured with a Cannon Power Shot S40 digital camera adapted to a Leica MZ-6 stereomicroscope.

\section{Results and Discussion}

Morphological characterization and comparisons

Bufonidae Gray, 1825

Bufo schneideri Werner, 1894 (Figures 1A, 9A)

Specimens examined. 11 tadpoles, stage 36 to 38, lot

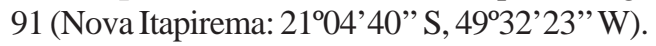

Characteristics. Total length $24.31 \pm 1.26$ mm (22.95
$-26.78 \mathrm{~mm}$ ). Body depressed, oval in dorsal view and globular/depressed in lateral view. Snout rounded in dorsal view and sloped in lateral view. Eyes small, dorsal and laterally directed. Nares large, oval, dorsally positioned with opening dorsolaterally directed, with a very small projection on the marginal rim. Spiracle sinistral, long and wide, opening on the posterior third of the body, laterally directed, centripetal wall totally fused to the body wall and longer than the external wall. Vent tube short, medial, fused with the ventral fin, with medial opening and ventral and dorsal walls of the same length. Oral disc anteroventral, emarginate laterally; row of marginal papillae uniseriate, with dorsal and ventral gaps; marginal papillae small, triangular, with three submarginal papillae laterally in the oral disc, forming a row on the inner side of the lateral emargination. Tooth row formula 2(2)/3; A-1 and A-2 of the same length, P-3 a little shorter than P-2. Jaw sheaths narrow, with triangular serration; upper jaw sheath "arc" shaped and lower jaw sheath "U" shaped, upper jaw sheath and lower jaw sheath of the same width. Dorsal fin low with convex margin, originating in the anterior third of the tail at a high slope; ventral fin low with margin parallel to the longitudinal axis of the tail. Dark coloration with translucent non-pigmented fins.

Comments. The tadpoles (treated as B. paracnemis) described by Rosa (1965) from Jaboticabal and by Vizotto (1967) from northwestern region, São Paulo State, Brazil, and by Cei (1980) from Argentinean populations differ from those described herein only by having an interrupted P-1 tooth row and by the absence of a submarginal papillae row. However, Rosa (1965) suggests that this interruption can be caused by damage during manipulation of the tadpoles.

\section{Hylidae Rafinesque, 1815}

Dendropsophus minutus (Peters, 1872) (Figures 1B, 9B)

Specimens examined. 10 tadpoles, stage 37 to 40 , lots: 15.3, 518 (Nova Itapirema: 2104'40” S, 49³2'23”' W), 459 (Macaúbas: 49³0’00”'W, 20³4’59" S).

Characteristics. Total length $37.52 \pm 2.96 \mathrm{~mm}$ (32.4$41.7 \mathrm{~mm}$ ). Body compressed, oval in dorsal view and triangular in lateral view. Snout rounded in dorsal view and sloped in lateral view. Eyes large, lateral, laterally directed. Nares large, circular, laterally positioned with opening posterodorsally directed, without projections on marginal rim. Spiracle sinistral, lateroventral, short and narrow, opening at the middle third of body, posterodorsally directed, centripetal wall fused to the body wall and longer than the external wall. Vent tube short, dextral, fused to the ventral fin, with medial opening and ventral wall shorter than dorsal wall. Oral disc anteroventral, not emarginate and with marginal papillae row uniseriate ventrally and biseriate laterally, with dorsal gap; marginal papillae triangular, long, with dorsal papillae shorter than ventral; submarginal papillae absent. Tooth row formula varies from $0 / 0$ to $0 / 1$ and $1 / 2$, with 
the last being more common; P-1 and P-2 of same length. Upper jaw sheath "arc" shaped and lower jaw sheath "U" shaped; upper jaw sheath narrower than the lower one. Dorsal fin low, with convex margin, emerging on the posterior third of the body at a high slope; ventral fin high, with convex margin; tail with flagellum. Coloration brown, with light stripes and blotches in body dorsum, opaque in the gular region and translucent in the belly region.

Comments. Three morphological characters vary among populations from different regions: total length, number of rows of marginal papillae and tooth row formula. The tadpoles here described are longer than those from Campo Grande, Mato Grosso State, Brazil (mean 30 mm, probably stage 39, Fig. 20, pag. 472; Bokermann 1963), but smaller than those studied by Kenny (1969) from Trinidad (40 mm, stage 31 to 39) and by Duellman (1978) from Ecuador (41,7 mm, stage 41). The tadpoles from Trinidad and Venezuela present a row of uniseriate marginal papillae (Kenny 1969, Duellman 1997), while those from Campo Grande have the oral disc with a row of marginal papillae biseriate ventrally, although the figure shows the row biseriate also laterally (Fig. 21, pag. 472; Bokermann 1963), and those from Ecuador present a marginal papilla row biseriate ventrally and laterally (Duellman 1978). In the population studied here the row of marginal papillae is biseriate only laterally. The tooth row formula varies from 0/1 (Bokermann 1963, Duellman 1997) to 0/2 (Duellman 1978) and 1/2 (Vizotto 1967, Kenny 1969, Cei 1980). These differences in the larvae from widely separated sites suggest the possibility of $D$. minutus being a species-complex, as noted by Duellman (1997), but the tooth row formula could vary even in the same population, as in the presently studied population. Vizotto (1967) reports that, during development, $D$. minutus tadpoles gradually lose labial tooth rows, first $\mathrm{P}-2$, followed by A-1, whereas the $\mathrm{P}-1$ row is more persistent. However, this sequence was not observed in the tadpoles described by Duellman (1978), that at the end of the larval stage (sensu Gosner 1960) have a tooth row formula of $0 / 2$, nor in the present study, where tadpoles at stages 36 and 40 presented a tooth row formula of $1 / 2$.

Dendropsophus nanus (Boulenger, 1889)

(Figures 1C, 9C)

Specimens examined. 13 tadpoles, stage 37, lots: 21.2 , 121.2 (Nova Itapirema: 2104'40”' S, 49³2’23”'W).

Characteristics. Total length $27.32 \pm 1.36 \mathrm{~mm}$ (25.37 - $29.76 \mathrm{~mm}$ ). Body compressed, oval in dorsal view and triangular/depressed in lateral view. Snout pointed in dorsal view and sloped in lateral view. Eyes large, lateral, laterally directed. Nares small, oval, laterally positioned with opening anterolaterally directed, without projections on marginal rim. Spiracle sinistral, lateroventral, long and narrow, opening on the middle third of the body, posterodorsally directed, centripetal wall fused with the body wall and the same length as the external wall. Vent tube short, dextral opening, positioned at the origin of the ventral fin, concealed by hind limbs. Oral disc anteroventral, modified to a protractile tube, without rows of marginal papillae or labial teeth. Jaw sheaths narrow, with triangular serration; upper jaw sheath "arc" shaped and lower jaw sheath "V" shaped. Dorsal fin high with convex margin, emerging on the posterior third of the body at a high slope; ventral fin low, with convex margin; tail with flagellum. Coloration reddish-brown, with light stripes between the eye and the snout, translucent fins, lightly pigmented, with non-pigmented areas forming light blotches.

Comments. These tadpoles are similar to those described by Bokermann (1963) from Campo Grande, São Paulo State, which differ from those described herein by the smaller total length and by the oral disc similar to a kind of " $U$ " shaped sucker. Lavilla (1990), on the basis of the geographical range of Dendropsophus nanus and Dendropsophus sanborni, considered that the tadpoles described by Bokermann (1963) belong to D. sanborni, and described the tadpole of $D$. nana from the Chaco region, Argentina, distinguishing them from $D$. sanborni tadpoles by the "violin" body shape, dorsal fin emerging at the middle of the body, and by the absence of a protractile tube in the former. The analysis of tadpoles used by Bokermann (1963) in his description (Lot: WCAB 13287) reveals that the oral disc presents a protractile tube and that the " $U$ " shaped structure described by the author is the anterior margin of the tube when it is retracted. These results indicate that the geographical distribution and the morphological characterization of Dendropsophus nanus and D. sanborni need to be better studied.

\section{Hypsiboas albopunctatus (Spix, 1824) (Figures 2A, 9D)}

Specimens examined. 35 tadpoles, stage 37 to 40 , lots: $170,180,478,503,520$ (Nova Itapirema: $21^{\circ} 04^{\prime} 40^{\prime \prime} \mathrm{S}$, 49³2'23”' W), 545, 546 (Engenheiro Schmidt: 2052'06”' S, 49¹6’40” W), 482 (Vitória Brasil: 20¹1’24" S, 50²8’48" W).

Characteristics. Total length $45.44 \pm 5.39$ mm (39.5$58.2 \mathrm{~mm}$ ). Body depressed, oval in dorsal view and globular/depressed in lateral view. Snout oval in dorsal view and rounded in lateral view. Eyes large, dorsal, laterally directed. Nares large, oval, dorsally positioned, with opening dorsolaterally directed, with a large projection on marginal rim. Spiracle sinistral, long and narrow, opening on the posterior third of the body, posteriorly directed, centripetal wall not fused to body wall and the same length of the external wall. Vent tube long, medial, fused to the ventral fin, with dextral opening and ventral wall longer than dorsal wall. Oral disc ventral, roughly triangular, emarginate ventrally; row of marginal papillae uniseriate with a narrow dorsal gap, 
submarginal papillae absent; marginal papillae long and triangular. Tooth row formula 2(1,2)/3(1), P-1 with a narrow interruption, less than three labial teeth; anterior tooth rows of the same length; P-3 half the length of P-2. Jaw sheaths narrow, with serration conical and long; upper jaw sheath "arc" shaped and lower jaw sheath "V" shaped; upper jaw sheath narrower than lower jaw sheath. Dorsal fin low and slightly convex, originating at the body-tail junction at a small slope; ventral fin low and parallel to the longitudinal tail axis. Coloration yellowish-brown, sometimes with black dots scattered throughout the dorsum, ventral region translucent in the belly region and opaque in the gular region, and irregularly pigmented with dark brown blotches; tail with a medium-lateral dark brown stripe on the anterior third of the tail muscle; translucent fins, with dark brown pigmentation accumulated in the posterior third of the fins.

Comments. The tadpoles described by de Sá (1995) differ from those studied herein by having a rounded snout, oval nares, eye positioned dorsolaterally, submarginal papillae and tooth row formula 2(2)/3(1). The tadpoles described by Heyer et al. (1990) from Boracéia, São Paulo State, differ from those studied herein by having a rounded snout. There are some variations in the tail muscle width among tadpole populations of this species. Tadpoles of $H$. albopunctatus are found generally in streams among the marginal vegetation, but some specimens were found in lentic (e.g. artificial pond) pools. In tadpoles found in streams, the width of the tail muscle is considerably larger than in those living in lentic ponds (tail muscle width/body width - stream dwelling tadpoles: $0.52 \pm 0.08, \mathrm{n}=9$; lentic dwelling tadpoles: $0.42 \pm 0.06, \mathrm{n}=10 ; \mathrm{t}=-3.22 ; \mathrm{p}<0.01$ ).

Hypsiboas lundii (Burmeister, 1856) (Figures 2B, 9E)

Specimens examined. 5 tadpoles stage 35 to 39, lot 521 (Mirassol: 49³1'15" W, 2049’09" S).

Characteristics. Total length $45.78 \pm 4.52 \mathrm{~mm}$ (40.1$52.4 \mathrm{~mm}$ ). Body depressed, ovoid in dorsal view and globular in lateral view. Snout oval in dorsal view and rounded in lateral view. Eyes small, dorsally positioned and dorsolaterally directed. Nares large, oval, dorsally positioned with opening dorsally directed, with a large projection on marginal rim. Spiracle sinistral, lateroventral, long and wide, opening on the posterior third of the body, posterodorsally directed, centripetal wall not fused to the body wall and longer than external wall. Vent tube long, dextral, fused to the ventral fin, with dextral opening and ventral wall longer than dorsal wall. Oral disc ventral, row of marginal papillae biseriate, with dorsal and ventral gaps; marginal papillae conical, long, with dorsal papillae shorter than ventral; few submarginal papillae laterally, with conical shape. Tooth row formula 2(2)/4(1). Jaw sheaths narrow, with triangular serration; upper jaw sheath "arc" shaped and lower jaw sheath "V" shaped. Dorsal fin low with convex margin and emerg- ing at the body-tail junction at a low slope; ventral fin low, with margin parallel to the longitudinal tail axis. Brown coloration, with small black dots scattered throughout the dorsum, fins translucent, lightly pigmented.

Comments. The tadpoles described by Bokermann \& Sazima (1973) (treated as Hyla biobeba) from Serra do Cipó, Minas Gerais State, Brazil, differ from those studied herein by having a longer total length (66 mm, stage 37), an oral disc not emarginate ventrally, and by having three rows of posterior labial tooth, although the figure shows four rows (Fig. 5, pg. 331; op. cit.).

\section{Hypsiboas raniceps (Cope, 1862) (Figures 2C, 9F)}

Specimens examined. 5 tadpoles, stages 34 to 37, lots: 22, 126(P1), 139, 142, 555 (Nova Itapirema: 2104’40” S, 49³2'23’'W).

Characteristics. Total length $57.58 \pm 8.07 \mathrm{~mm}$ (52.6 $66.9 \mathrm{~mm}$ ). Body globular, ovoid in dorsal view and globular/ depressed in lateral view. Snout oval in dorsal view and rounded in lateral view. Eyes small, dorsal, dorsally directed. Nares large, oval, dorsally positioned with opening dorsally directed, with a large projection on marginal rim. Spiracle sinistral, long and narrow, opening on the posterior third of the body, posteriorly directed, with centripetal wall not fused with the body wall and of the same length as the external wall. Vent tube long, medial, fused with the ventral fin, with dextral opening and ventral and dorsal wall of the same length. Oral disc ventral, emarginate ventrally; row of marginal papillae uniseriate, with narrow dorsal gap; marginal papillae small, triangular, with one or two submarginal papillae laterally. Tooth row formula 2(1,2)/3(1); anterior labial tooth rows of the same length, P-2 longer than P-1 and P-3. Jaw sheaths wide, with triangular serration; upper jaw sheath "arc" shaped and lower jaw sheath "V" shaped; upper and lower jaw sheath of the same width. Dorsal fin high, with triangular margin, emerging on the posterior third of the body at a high slope; ventral fin low, about half the height of the tail muscle. Coloration reddish-brown, with small black dots scattered throughout the body dorsum and dark brown rectangular blotches in the dorsal region of the tail muscle along the longitudinal tail axis.

Comments. These tadpoles are similar to those described by Vizotto (1967), from Ibirá, São Paulo State, Brazil. The tadpoles characterized by Cei (1980) from Argentinean populations, differ from the population here studied by having a dextral vent tube, narrower upper jaw sheath and a tooth row formula 2/3(1).

Pseudis paradoxa (Linnaeus, 1758) (Figures 3A, 9G)

Specimens examined. 11 tadpoles, stage 37, lots: 553, 554 (Ribeirão Preto: 4748’37" W, 2110’39" S).

Characteristics. Total length $185.55 \pm 15.30 \mathrm{~mm}$ (169.1 
- $208.23 \mathrm{~mm}$ ). Body compressed, oval in dorsal view and globular/triangular in lateral view. Snout truncate in dorsal view and sloped in lateral view. Eyes small, lateral, laterally directed. Nares small, oval, dorsally positioned with opening laterally directed, with a small projection on the marginal rim. Spiracle sinistral, short and narrow, opening on the middle third of the body, posteriorly directed, centripetal wall not fused with the body wall and longer than the external wall. Vent tube long, medial, fused to the ventral fin, with ventral and dorsal wall of the same length, medial opening. Oral disc ventral, emarginate ventrally; row of marginal papillae biseriate, with a narrow dorsal gap; marginal papillae long, conical, with five to six submarginal papillae scattered laterally and ventrally. Tooth row formula 2(2)/3(1); A-1 and A-2 of the same length, P-2 longer than P-3. Jaw sheaths narrow, with very short and conical serration; upper jaw sheath "arc" shaped and lower jaw sheath "V" shaped; upper jaw sheath wider than the lower one. Dorsal fin high, with convex margin, emerging on the anterior third of the body at a small slope; ventral fin high, with a convex margin. Coloration grayish-brown, with dark spots and non-pigmented areas scattered throughout the body and tail.

Comments. These tadpoles are larger than those described by Vizotto (1967) from Icém, São Paulo State (168 mm, stage 38), and larger than those from Cáceres, Minas Gerais State, Brazil, described by Miranda-Ribeiro (1926; 105 mm, probably stage 38). Vizotto (1967) considered these tadpoles to have large eyes compared to the interocular distance. In the present study, we used body length as reference to qualify the eyes as small. The tooth row formula of the Cáceres specimen (2/3; Miranda-Ribeiro 1926) differs from other descriptions (Vizotto 1967, Cei 1980) and from the present one [2/ 3(1)]. Vizotto (1967) suggests that this difference may be due the poor preservation of the Cáceres specimen.

Scinax fuscomarginatus (A. Lutz, 1925)

(Figures 3B, 9H)

Specimens examined. 6 tadpoles, stage 37, lots: 25,

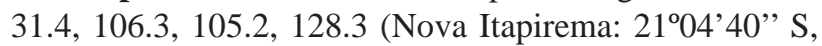
49³2'23’'W).

Characteristics. Total length $27.11 \pm 0.83 \mathrm{~mm}$ (26.30 - $28.05 \mathrm{~mm}$ ). Body compressed, oval in dorsal view and triangular/depressed in lateral view. Snout rounded in dorsal and lateral view. Eyes large, lateral, laterally directed. Nares large, circular, dorsolaterally positioned with opening dorsolaterally directed, without projection on marginal papillae. Spiracle sinistral, short and narrow, opening on the middle third of the body, posterodorsally directed, centripetal wall fused to the body wall and longer than the external wall. Vent tube short, dextral, fused to the ventral fin, with ventral opening and ventral and dorsal wall as the same length. Oral disc anteroventral, emarginate ventrally; row of uniseriate marginal papillae, with dorsal gap; marginal papillae long, conical; submarginal papillae aggregate laterally in the oral disc. Tooth row formula 2(2)/3(1); A-1 and A2 of the same length and P-2 longer than P-1 and P-3. Jaw sheaths narrow with triangular serration; upper jaw sheath "arc" shaped and lower jaw sheath "U" shaped; upper and lower jaw sheaths of the same width. Dorsal fin high with a convex margin, emerging on the anterior third of the body at a high slope; ventral fin high with a convex margin; tail with flagellum; dorsal tail muscle highly developed concealing the limit between the end of the body and the beginning of the tail. Coloration light brown with a dark stripe between the snout and the eyes and melanophores grouped at the spiracle base, a mediolateral stripe on the anterior third of the tail muscle, fins translucent, lightly pigmented, with marginal dark blotches on the posterior third of the tail.

Comments. These tadpoles are similar to those described by Vizotto (1967) (treated as Hyla parkeri), from Nova Itapirema, São Paulo State, Brazil, which differ from those described herein by the row of marginal papillae biseriate laterally and by the medial vent tube. The author reports the tooth row formula $2(2) / 3$, but denotes a tendency for bipartition of P-1.

\section{Scinax fuscovarius (A. Lutz, 1925) (Figures 4A, 10A)}

Specimens examined. 10 tadpoles, stage 37 to 39 ,

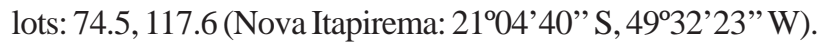

Characteristics. Total length $38.50 \pm 1.65$ mm (36.70 - $41.57 \mathrm{~mm}$ ). Body compressed, oval in dorsal view and triangular in lateral view. Snout rounded in dorsal view and sloped in lateral view. Eyes large, lateral, laterally directed. Nares large, oval, dorsolaterally positioned with opening laterally directed, without projection on the marginal rim. Spiracle sinistral, long and narrow, opening on the posterior third of the body, posteriorly directed, centripetal wall fused to the body wall and longer than the external wall. Vent tube long, dextral, fused to the ventral fin, with a ventral opening, ventral and dorsal wall of the same length. Oral disc anteroventral, emarginate ventrally; row of marginal papillae uniseriate, with dorsal gap; marginal papillae long, conical; submarginal papillae smaller than the marginal ones, forming rows laterally in the oral disc. Tooth row formula 2(2)/3(1); A-1 and A-2 of the same length, P-3 slightly smaller than P-2. Jaw sheaths wide, with conical serration; upper jaw sheath "M" shaped and lower jaw sheath "V" shaped; upper jaw sheath narrower than lower jaw sheath. Dorsal fin high, with a convex margin, emerging on the middle third of the body at a high slope; ventral fin high, with a convex margin; tail with flagellum. Coloration silver-grayish, with small dark spots scattered all over the body; fins translucent without pigments.

Comments. These tadpoles are similar to those described by Vizotto (1967) from northwestern region of São 
Paulo State, Brazil, and by Cei (1980), from Argentinean populations. The tadpoles described herein differ from the former descriptions by the absence of 4 to 6 rows of submarginal papillae in the lateral region of the oral disc.

Scinax similis (Cochran, 1952) (Figures 4B, 10B)

Specimens examined. 10 tadpoles, stage 37 and 38, lot 21.6 (Nova Itapirema: 2104'40” S, 49³2’23”'W).

Characteristics. Total length $28.47 \pm 1.63 \mathrm{~mm}$ (25.68 - $30.39 \mathrm{~mm})$. Body compressed, oval in dorsal view and triangular in lateral view. Snout rounded in dorsal view and sloped in lateral view. Eyes large, lateral, laterally directed. Nares large, rounded/circular, dorsolaterally positioned with opening directed dorsolaterally, without projection on the marginal rim. Spiracle sinistral, long and narrow, opening on the posterior third of the body, posterodorsally directed, centripetal wall fused with the body wall and longer than the external wall. Vent tube short, dextral, fused to the ventral fin, with ventral opening and ventral and dorsal wall of the same length. Oral disc anteroventral, emarginate ventrally; row of marginal papillae uniseriate, with dorsal gap; marginal papillae long and conical; submarginal papillae shorter than the marginal ones, laterally aggregate in the oral disc. Tooth row formula 2(2)/3(1); A-1 and A-2 of the same length, P3 slightly shorter than P-2. Jaw sheaths wide, with triangular serration; upper jaw sheath " $M$ ” shaped and lower jaw sheath "V" shaped, upper and lower jaw sheath of the same width. Dorsal fin high, with convex margin, emerging on the middle third of the body at a high slope; ventral fin high, with convex margin; tail with flagellum. Coloration light brown, tail muscle with mediolateral and mediodorsal dark stripes, fins lightly pigmented, marginally mottled.

Comments. The tadpoles described by Alves \& Carvalho-e-Silva (1999), from Rio de Janeiro State, Brazil, differ from those studied herein by a longer total length (31 mm at stage 37 ), globular body, oval nares, spiracle opening posterodorsally directed and submarginal papilla distribution, with some papillae forming an irregular row and others distributed in a disorganized way.

Trachycephalus venulosus (Laurenti, 1768) (Figures 4C, 10C)

Specimens examined. 10 tadpoles, stage 37 and 38 ,

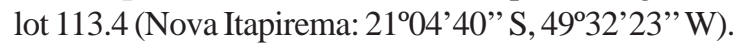

Characteristics. Total length $43.85 \pm 1.03$ mm (42.47 $-45.05 \mathrm{~mm}$ ). Body globular, oval in dorsal view and triangular/depressed in lateral view. Snout rounded in dorsal view and sloped in lateral view. Eyes small, lateral, laterally directed. Nares small, oval, dorsolaterally positioned with opening anterolaterally directed, without projection on the marginal rim. Spiracle sinistral, lateroventral, long and narrow, opening on the middle third of the body, posterodorsally directed, centripetal wall fused with body wall and the same length as the external wall. Vent tube short, medial, fused to the ventral fin, with medial opening and ventral and dorsal wall of the same length. Oral disc anteroventral, emarginate ventrally; row of marginal papillae biseriate, with dorsal gap; marginal papillae short, triangular; submarginal papillae conical, of the same length as the marginal papillae, distributed laterally, forming rows. Tooth row formula 4(1,2,4)/6(1,6); A1 and A-2 fragmented and A-3 shorter than A-4, P-6 fragmented. Jaw sheaths narrow, with triangular serration; upper jaw sheath "arc" shaped and lower jaw sheath "V" shaped; upper jaw sheath wider than lower jaw sheath. Dorsal fin low, with convex margin, emerging on the middle third of the body at a median slope; ventral fin low, with convex margin; tail with flagellum. Coloration brown, translucent fins lightly pigmented, with non-pigmented areas forming light blotches.

Comments. These tadpoles are similar to those analyzed by Duellman (1970), from Panamá and México populations (treated as Phrynohyas venulosa), from which those studied herein differ only by presenting a ventral fin lower than the dorsal fin.

\section{Leptodactylidae Werner, 1896}

Eupemphix nattereri Steindachner, 1863 (Figures 5A, 10D)

Specimens examined. 10 tadpoles, stage 35 to 39, lots: 113.6, 117.4 (Nova Itapirema: 2104'40”' S, 49³2’23”'W).

Characteristics. Total length $32.64 \pm 1.02$ mm (30.37 - $33.93 \mathrm{~mm}$ ). Body globular, ovoid in dorsal view and globular in lateral view. Snout pointed in dorsal view and sloped in lateral view. Eye small, dorsal, dorsolaterally directed. Nares small, circular, dorsally positioned with opening dorsally directed, without projection on the marginal rim. Spiracle sinistral, long and wide, opening on the middle third of the body, posterodorsally directed, centripetal wall totally fused to the body wall and the same length as the external wall. Vent tube short, dextral, fused to the ventral fin, dextrally directed, with ventral and dorsal membrane of the same length. Oral disc ventral, emarginate laterally; row of marginal papillae uniseriate, with dorsal gap; marginal papillae long, conical; submarginal papillae absent. Tooth row formula 2(2)/3(1); A-1 shorter than A-2, P-2 slightly longer than $\mathrm{P}-1$ and $\mathrm{P}-3$. Jaw sheaths narrow, with triangular serration; upper jaw sheath "arc" shaped and lower jaw sheath "V" shaped; upper and lower jaw sheath of the same width. Dorsal fin low, with convex margin, emerging on the posterior third of the body at a median slope; ventral fin low, with margin parallel to the longitudinal axis of the tail muscle. Coloration brown, with tail muscle pigmented and fins translucent and slightly pigmented. 
Comments. The tadpoles described by Vizotto (1967) from the northwestern region of the São Paulo State, Brazil, differ from those studied herein by having a medial vent tube. The tadpoles described by Cei (1980) from Argentinean populations, differ from those studied herein by the presence of submarginal papillae and wider jaw sheath.

\section{Leptodactylus fuscus (Schneider, 1799)} (Figures 5B, 10E)

Specimens examined. 10 tadpoles, stage 37 , lot 117.1

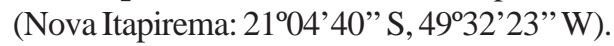

Characteristics. Total length $27.76 \pm 2.30 \mathrm{~mm}$ (24.35 $-31.28 \mathrm{~mm}$ ). Body depressed, oval in dorsal view and globular/depressed in lateral view. Snout oval in dorsal view and sloped in lateral view. Eyes small, dorsal, laterally directed. Nares small, oval, dorsally positioned with opening laterally directed, without projection on the marginal rim. Spiracle sinistral, short and narrow, posterodorsally directed, opening on the middle third of the body, centripetal wall totally fused with the body wall and the same length as the external wall. Vent tube long, medial, fused to the ventral fin, with medial opening and ventral membrane longer than the dorsal one. Oral disc anteroventral, not emarginate; row of uniseriate marginal papillae, with a dorsal gap; marginal papillae long, triangular, submarginal papillae absent. Tooth row formula 2(2)/3(1); A-1 shorter than A-2; P-2 longer than P-1 and P-3. Jaw sheaths narrow, with triangular serration; upper jaw sheath "arc" shaped and lower jaw sheath "V" shaped; upper and lower jaw sheath of the same width. Dorsal fin low with a convex margin, emerging on the posterior third of the body at a low slope; ventral fin low, margin parallel to the longitudinal axis of the tail muscle. Coloration of the body and tail muscle dark brown in the dorsal-half and brownish-cream in the ventral-half.

Comments. These tadpoles are similar to those described by Lescure (1973) from French Guyana (Surinam), differing from those studied herein by having a biseriate row of marginal papillae.

Leptodactylus labyrinthicus Spix, 1824 (Figures 5C, 10F)

Specimens examined. 10 tadpoles, stage 36 to 39, lot 542 (São José do Rio Preto: 49²2’45" W, 2049’10" S).

Characteristics. Total length $48.10 \pm 2.22 \mathrm{~mm}$ (45.30 $-50.00 \mathrm{~mm}$ ). Body depressed, oval in dorsal view and globular/depressed in lateral view. Snout rounded in dorsal and lateral views. Eye small, dorsal, dorsolaterally directed. Nares small, oval, positioned dorsally with opening dorsolaterally directed, without projection on the marginal rim. Spiracle sinistral, lateroventral, short and wide, posterodorsally directed, opening on the middle third of the body, centripetal wall totally fused with the body wall and longer than the external wall. Vent tube long, medial, fused to the ventral fin, opening medially directed and ventral wall longer than dorsal wall. Oral disc anteroventral, emarginate ventrally; row of marginal papillae uniseriate, with dorsal gap, marginal papillae short, conical, submarginal papillae absent. Tooth row formula 1/2(1); P-1 longer than P-2. Jaw sheaths narrow, with conical serration; upper jaw sheath "arc" shaped and lower jaw sheath "V” shaped; upper and lower jaw sheath of the same width. Dorsal fin low with margin parallel to the longitudinal axis of the tail muscle, emerging on the posterior third of the body at a low slope; ventral fin low, margin parallel to the longitudinal axis of the tail muscle. Coloration uniformly grayish-brown, with light blotches and stripes. Fins translucent, slightly pigmented, with accumulation of pigments on the posterior third.

Comments. These tadpoles differ from those studied by Vizotto (1967) from the northwestern region of São Paulo State, Brazil, only in total length (65 mm, stage 38) and eye size, which the author considered to be large.

\section{Leptodactylus ocellatus (Linnaeus, 1758)} (Figures 6A, 10G)

Specimens examined. 10 tadpoles, stage 38 and 39,

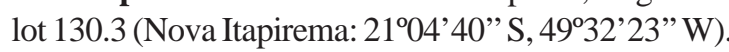

Characteristics. Total length $58.68 \pm 2.08 \mathrm{~mm}(55.5-$ $61.2 \mathrm{~mm}$ ). Body depressed, elongated-oval in dorsal view and globular/depressed in lateral view. Snout oval in dorsal view and rounded in lateral view. Eye small, dorsal, dorsolaterally directed. Nares small, rounded, dorsally positioned with opening dorsally directed, without projection on the marginal rim. Spiracle sinistral, lateroventral, posterodorsally directed, long and wide, opening on the middle third of the body, centripetal wall fused to the body wall with free distal edge and the same length as the external wall. Vent tube long, medial, fused to the ventral fin, opening medially directed, and ventral wall longer than dorsal wall. Oral disc anteroventral, emarginate ventrally; row of marginal papillae biseriate ventrally and triseriate laterally, with dorsal gap; marginal papillae long, triangular; one submarginal papilla longer than the marginal one. Tooth row formula 2/3; A-1 and A-2 of the same length; P-2 of the same length as P-1 and slightly longer than P-3. Jaw sheaths narrow, with triangular serration; upper jaw sheath "arc" shaped and lower jaw sheath "U" shaped; upper and lower jaw sheath of the same width. Dorsal fin low with convex margin, emerging at the tail-body junction at a low slope; ventral fin low, with convex margin. Coloration black. Fins translucent and heavily pigmented.

Comments. These tadpoles differ from those described by Fernandez \& Fernandez (1921) only by the shorter length of the Argentinean specimens (54 mm), and from those studied by Cei (1980), also from Argentina, only by body shape, which that author considered to be ovoid in dorsal view. 


\section{Leptodactylus podicipinus (Cope, 1862) (Figures 6B, 10H)}

Specimens examined. 10 tadpoles, stage 37 , lot 123.3 (Nova Itapirema: 2104’40”' S, 49³2'23”'W).

Characteristics. Total length $25.03 \pm 0.85 \mathrm{~mm}$ (24.02 - $26.50 \mathrm{~mm})$. Body depressed, elongated-oval in dorsal view and globular/depressed in lateral view. Snout oval in dorsal view and sloped in lateral view. Eye small, dorsal, dorsolaterally directed. Nares small, oval, dorsally positioned with opening laterally directed, without projection on the marginal rim. Spiracle sinistral, short and narrow, posterodorsally directed, opening on the middle third of the body, centripetal wall fused to the body wall with free distal edge and of the same length as the external wall. Vent tube long, medial, fused to the ventral fin, with medial opening and ventral wall longer than dorsal wall. Oral disc anteroventral, emarginate ventrally; row of marginal papillae biseriate ventrally, triseriate laterally, with dorsal gap; marginal papillae short and conical, submarginal papillae absent. Tooth row formula 2(2)/3; A-1 and A-2 of the same length and P-3 slightly shorter than P-2. Jaw sheaths narrow, with conical serration; upper jaw sheath "arc" shaped and lower jaw sheath "V" shaped; upper and lower jaw sheaths of the same width. Dorsal fin low, with convex margin, emerging on the posterior third of the body at a low slope; ventral fin low with margin parallel to the longitudinal axis of the tail muscle. Coloration black, with fins heavily pigmented.

Comments. These tadpoles are similar to those described by Vizotto (1967), from northwestern region of São Paulo State, Brazil. Tadpoles from Trinidad (Kenny 1969) are larger (max. length of $35 \mathrm{~mm}$ ) than tadpoles from other localities, they have a ventral gap on the row of marginal papillae, and have ventral papillae shorter than the lateral ones.

Physalaemus centralis Bokermann, 1962 (Figures 6C, 11A)

Specimens examined. 13 tadpoles, stage 37, lot JJ6942 (Nova Itapirema: 2104'40”' S, 49³2'23”' W).

Characteristics. Total length $20.20 \pm 0.93$ mm (18.60 $-21.70 \mathrm{~mm}$ ). Body depressed, ovoid in dorsal view and globular/depressed in lateral view. Snout rounded in dorsal and lateral views. Eye small, dorsal, dorsolaterally directed. Nares small, circular, dorsally positioned with opening dorsally directed, with a very small projection on the marginal rim. Spiracle lateroventral, short and narrow, opening on the middle third of the body, ventrally directed, centripetal wall totally fused to the body wall and the same length as the external wall. Vent tube long, medial, with free distal edge and ventral and dorsal membrane of the same length. Oral disc ventral, emarginate laterally; row of marginal papillae uniseriate, with dorsal and lateroventral gap, forming a ventral ridge with a variable number of papillae, no more than ten; marginal papillae long, conical, submarginal papillae absent. Tooth row formula 2(2)/2; A-1 and A-2 of the same length, P-2 slightly shorter than P-1. Jaw sheaths wide, with triangular serration; upper jaw sheath "arc” shaped and lower jaw sheath "V" shaped; lower jaw sheath wider than the upper one. Dorsal fin low, with convex margin, emerging at the posterior third of the body at a low slope; ventral fin low, with margin parallel to the longitudinal axis of the tail muscle. Coloration brown, fins translucent, with marginal dark blotches, concentrated in the posterior third of the tail.

Comments. These tadpoles were described by RossaFeres \& Jim (1993) and no further references were found.

\section{Physalaemus cuvieri Fitzinger, 1826 (Figures 7A, 11B)}

Specimens examined. 11 tadpoles, stage 37 to 39 , lot

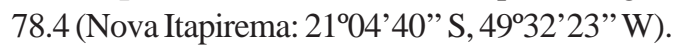

Characteristics. Total length $23.49 \pm 0.86 \mathrm{~mm}$ (21.79 - $24.86 \mathrm{~mm}$ ). Body depressed, ovoid in dorsal view and globular/depressed in lateral view. Snout rounded in dorsal and lateral views. Eye small, dorsal, dorsolaterally directed. Nares large, oval, dorsally positioned with opening dorsally directed, with a small projection on marginal rim. Spiracle sinistral, long and wide, opening on the posterior third of the body, posterodorsally directed, centripetal wall fused to the body wall with free distal edge and longer than the external wall. Vent tube long, medial, with opening medially directed and ventral and dorsal wall of the same length. Oral disc ventral, emarginate laterally; row of marginal papillae uniseriate, with ventral, lateroventral and dorsal gaps; marginal papillae long, conical, submarginal papillae absent. Tooth row formula 2(2)/3(1); A-1 and A-2 of the same length and P-3 about a third of P-2 length. Jaw sheaths narrow, with triangular serration; upper jaw sheath "arc” shaped and lower jaw sheath "U” shaped; lower jaw sheath wider than the upper one. Dorsal fin low, with convex margin, emerging on the posterior third of the body at a low slope; ventral fin low with margin parallel to the longitudinal axis of tail muscle. Coloration brown, with translucent fins slightly pigmented.

Comments. The tadpoles described by Bokermann (1962) from Coluene river, at Posto Jacaré, Mato Grosso State, Brazil, differ from those studied herein by the longer total length and tooth row formula 2/3(1). Cei (1980), for Argentinean populations, reports a dextral vent tube with opening directed dextrally, instead of the medial vent tube with opening medially directed, as in the population studied herein. 


\section{Physalaemus fuscomaculatus (Steindachner, 1864) (Figures 7B, 11C)}

Specimens examined. 43 tadpoles, stage 37 to 40 , lots: 15.6, 118.4 (Nova Itapirema: 2104'40” S, 49³2’23”'W).

Characteristics. Total length $23.32 \pm 1.37 \mathrm{~mm}(22.0-$ $25.59 \mathrm{~mm}$ ). Body depressed, ovoid in dorsal view and globular/depressed in lateral view. Snout oval in dorsal view and rounded in lateral view. Eye small, dorsal, dorsolaterally directed. Nares large, circular, dorsally positioned with opening dorsally directed, with a very small projection on the marginal rim. Spiracle sinistral, long and narrow, opening on the middle third of the body, posterodorsally directed, centripetal wall fused to the body wall with free distal edge and the same length as the external wall. Vent tube, medial, fused to the ventral fin, opening dextrally directed, with ventral wall longer than the dorsal one. Oral disc ventral, emarginate laterally, row of marginal papillae uniseriate, with dorsal gap and two narrow ventral gaps, forming a ventral ridge with a variable number of papillae, 8 to 18, marginal papillae long and conical, one to five submarginal papillae, longer than the marginal ones, laterally on the oral disc. Tooth row formula 2(2)/2(1); A-1 and A-2 of the same length, P-2 slightly shorter than P-1. Jaw sheaths wider, upper jaw sheath "M" shaped and lower jaw sheath "V" shaped; upper and lower jaw sheaths of the same width, with triangular serration. Dorsal fin low with convex margin, emerging on the posterior third of the body at a low slope; ventral fin low with margin parallel to the longitudinal axis of the tail muscle. Coloration brown, with dorsum scattered with dark dots, forming a semicircular arch around the internal margin of the nares. Belly translucent. Tail muscle light brown, with scattered blotches. Fins translucent, with light reticulate formed by blood vessels and with some blotches marginally to the dorsal and ventral fins.

Comments. These tadpoles were described by Nomura et al. (2003) and no further references were found.

\section{Microhylidae Günther, 1858}

Dermatonotus muelleri (Boettger, 1885)

(Figures 7C, 11D)

Specimens examined. 10 tadpoles, stage 37 to 40 , lot 481 (Vitória Brasil: 20¹1’24" S, 50²8’48" W).

Characteristics. Total length $38.38 \pm 2.47 \mathrm{~mm}$ (33.2 $41.7 \mathrm{~mm}$ ). Body globular, rounded in dorsal view and globular/depressed in lateral view. Snout rounded in dorsal view and truncate in lateral view. Eyes small, lateral, laterally directed. Nares absent. Spiracle ventral, long and wide, opening on the posterior third of the body, posteriorly directed, centripetal wall not fused with the body wall and the same length as the external wall. Vent tube short, medial, fused with the ventral fin, with a medial opening and with ventral and dorsal membranes of the same length. Oral disc absent, without keratinized mouthparts or papillae; dermal flap in front of the mouth, dermal flap edges not jagged. Dorsal and ventral fins low, with a convex margin. Dorsal fin emerging at the body-tail junction at a low slope. Dorsal-half coloration reddish-brown and ventral-half light cream. Fins translucent, slightly pigmented, mostly in the anterior third.

Comments. These tadpoles are smaller than those described by Vizotto (1967), from Santa Fé do Sul, São Paulo State, Brazil, which measured $40 \mathrm{~mm}$ in total length (stage 37), but the same length as the tadpoles from Embarcación, Argentina, studied by Lavilla (1992). Vizotto (1967) considered the tadpoles to have large eyes (see comment in Pseudis paradoxa, above) and Cei (1980) considered the eyes to be dorsolaterally directed rather than laterally, and the mouth ventrally rather than anteroventrally directed, as in the present description. Lavilla (1992) also considered these tadpoles to have large eyes, laterally positioned, but dorsolaterally directed, as also reported by Cei (1980).

Elachistocleis bicolor (Guérin-Méneville, 1838) (Figures 8A, 11E)

Specimens examined. 10 tadpoles, stage 36 to 38, lots: 21.1, 65.1 (Nova Itapirema: 2104'40”' S, 49³2’23”'W).

Characteristics. Total length $21.81 \pm 0.22 \mathrm{~mm}$ (21.51 $-22.05 \mathrm{~mm}$ ). Body depressed, rounded in dorsal view and triangular/depressed in lateral view. Snout rounded in dorsal view and truncate in lateral view. Eyes small, lateral, laterally directed. Nares absent. Spiracle ventral, long and wide, sinistral, opening dorsally directed, centripetal wall fused to the vent tube and shorter than the external wall. Vent tube long, medial, fused to the ventral fin, with sinistral opening and ventral and dorsal wall of the same length. Oral disc without keratinized mouthparts or papillae; paired dermal flap suspended in front of the mouth, dermal flap edges mostly not jagged. Dorsal fin low, with convex margin, emerging on the posterior third of the body at a low slope; ventral fin low, with a convex margin. Coloration dark brown, with light stripes and dots between the snout and eye and ventrolaterally on the body; medial stripe on the anterior third of the tail muscle, fins translucent and slightly pigmented, marginally mottled with dark brown blotches on the anterior third of the dorsal fin.

Comments. According to Frost (2004), the cited nomenclature and distribution for the Elachistocleis species are provisory and almost certainly partially wrong. Three major factors contribute to this taxonomic difficulty: the nomenclatural uncertainty, the distribution of Elachistocleis species, which is more complex than any continental-level synthesis has proposed, and the absence of statistical analysis of the intra- and inter- variation of the proposed Elachistocleis species (Frost 2004). The tadpoles studied 
were assigned to $E$. bicolor based on the distributional range presented by Lavilla et al. (2003). The characterization of the tadpoles is also confuse: according to Orton (1953), tadpoles of Microhylidae have medial spiracle and vent tube with opening directed medially, a condition considered typical for this family and utilized by Orton (1953) in her proposal of anuran classification. However, Griffiths \& Carvalho (1965), Kenny (1969) and Rada de Martinez (1981) described the spiracle and the vent tube sinistral, with a sinistral opening. Lavilla \& Langone (1991) proposed that these differences are a consequence of a change in the direction of the spiracle and the vent tube openings from sinistral to medial during tadpole development. Lavilla \& Langone (1991) considered the spiracle, as described and illustrated by Griffiths \& Carvalho (1965), to be simply sinistral, without mention the fact that the vent tube and spiracle were fused together in a single tube in the tadpole drawing, differing from those studied by the authors, that open in distinct tubes. These tadpoles are associated with adult forms having an uniform yellow, spotless (immaculated) venter.

\section{Elachistocleis sp. (Figures 8B, 11F)}

Specimens examined. 10 tadpoles, stage 37, lots: 486, 487, 488, 489, 490 (Vitória Brasil: 20¹1’24" S, 50²8’48"W).

Characteristics. Total length $29.65 \pm 1.47 \mathrm{~mm}$ (27.2 $30.5 \mathrm{~mm}$ ). Body depressed, rounded in dorsal view and triangular/depressed in lateral view. Snout pointed, with a medial depression, in dorsal view and truncate in lateral view. Eyes small, lateral, dorsolaterally directed. Nares absent. Spiracle ventral, medial, long and wide, sinistral, opening dorsally directed, with centripetal wall fused with the vent tube and shorter than the external wall. Vent tube long, medial, fused to the ventral fin, with sinistral opening and ventral wall longer than the dorsal wall. Oral disc without keratinized mouthparts or papillae; paired dermal flap in front of the mouth; dermal flap edges jagged. Dorsal fin low, with convex margin, emerging at the body-tail junction at a low slope; ventral fin low, with a convex margin. Dark brown coloration, with light stripes and blotches between the eye and the snout and ventrally on the body, medial light cream stripe on the vertebral line and, in lateral view, on the anterior third of the tail muscle, fins translucent and slightly pigmented, mottled with marginal dark brown blotches on the anterior third of the dorsal fin and posterior third of the ventral fin.

Comments. Tadpoles of the genera Elachistocleis, collected in Vitória Brasil, São Paulo State, Brazil, have the vent tube and spiracle fused according to the drawing for $E$. ovalis published by Griffiths \& Carvalho (1965). These tadpoles are associated with adult forms presenting a dark gray, with orange spots (maculated) venter.

\section{Taxonomic key}

1 Without nares; spiracle ventral; body rounded in dorsal view; dermal flap in front of the mouth .......................... 2

- With nares; spiracle sinistral; body not rounded in dorsal view; mouth without dermal flap.

2 Single mouth flap; spiracle and vent tube not fused; total length more than $35 \mathrm{~mm}$....... Dermatonotus muelleri

- Paired mouth flap; spiracle and vent tube fused; total length less than $31 \mathrm{~mm}$....

3

3 Mouth dermal flap not jagged; eyes laterally directed; snout rounded in dorsal view .. Elachistocleis bicolor

- Mouth dermal flap jagged; eyes dorsolaterally directed; snout pointed in dorsal view ............................................................ Elachistocleis sp.

4 Large tadpoles, with total length more than $100 \mathrm{~mm}$; .Pseudis paradoxa

- Tadpoles with total length below $70 \mathrm{~mm}$;

5 Oral disc without marginal papillae or labial tooth rows, oral tube present Dendropsophus nanus

- Oral disc with marginal papillae and labial tooth rows, oral tube absent 6

6 Eyes lateral; body triangular in lateral view ..................... 7

- Eyes dorsal; body not triangular in lateral view .............. 11

7 Oral disc anterior; tooth row formula $0 / 0,0 / 1$ or $1 / 2$ . Dendropsophus minutus

- Oral disc ventral; tooth row formula not as above ........... 8

8 Tooth row formula $4(1,2,4) / 6(1,6)$; nares opening anterolaterally ..................... Trachycephalus venulosus

- Tooth row formula 2(2)/3(1); nares opening laterally ..... 9

9 Body height one-half the body length; snout rounded in lateral view; jaw sheaths narrow ................................................. Scinax fuscomarginatus

- Body height almost two-thirds the body length; snout sloped in lateral view; jaw sheaths wide ...................... 10

10 Total length of more than $31 \mathrm{~mm}$; dorsal fin emerging at the eye plane, with a slope of more than $30^{\circ}$; submarginal papillae of unequal size Scinax fuscovarius

- Total length of more than $28 \mathrm{~mm}$; dorsal fin emerging posteriorly to the eye plane, with a less than $30^{\circ}$ slope; submarginal papillae of equal size .... Scinax similis

11 Spiracle with centripetal wall not fused to the body wall .. 12

- Spiracle with centripetal wall totally fused to the body wall or only with distal edge free..... 14 
12 Tooth row formula 2(2)/4; oral disc with three ventral emarginations, with many submarginal papillae; marginal papillae biseriate; nares small, with nares length shorter than one-half the ocular diameter; spiracle wider than longer Hypsiboas lundii

- Tooth row formula 2(1,2)/3(1); oral disc with two ventral emargination, with one or two submarginal papillae or submarginal papillae absent; nares large, with nares length longer than one-half the ocular diameter; spiracle longer than wider

13

13 Tail muscle wide in dorsal view, more than one-third the body width; margin of dorsal fin convex .. Hypsiboas albopunctatus

- Tail muscle narrow in dorsal view, less than one-third the body width; margin of dorsal fin triangular . Hypsiboas raniceps

14 Oral disc with three rows of posterior labial teeth not interrupted... .15

- Oral disc with three rows of posterior labial teeth, with at least one row interrupted, or with two rows of posterior labial teeth 17

15 Body oval in dorsal view; caudal fins not pigmented; marginal papillae of oral disc with dorsal and ventral gaps; nares length longer than one-half the ocular diameter Bufo schneideri

- Body oval-elongated in dorsal view; caudal fins pigmented; marginal papillae of oral disc with dorsal gap only; nares length shorter than one-half the ocular diameter ......... 16

16 Total length more than $53 \mathrm{~mm}$; labial tooth row A-2 not interrupted.... Leptodactylus ocellatus

- Total length below 26 mm; labial tooth row A-2 interrupted . Leptodactylus podicipinus

17 Tooth row formula 1/2(1); oral disc not emarginate laterally; tail length almost four-fold longer than body length; vertical white stripes around the snout Leptodactylus labyrinthicus

- Tooth row formula not as above; oral disc emarginate laterally; tail length up to two-fold the body length; without vertical white stripes around the snout 18

18 Tooth row formula with three posterior labial tooth rows ... 19

- Tooth row formula with two posterior labial tooth rows 21

19 Oral disc with reduced P-3 labial tooth row, almost onethird the P-2; row of marginal papillae with ventral gap; nares length longer than one-half the ocular diameter; centripetal wall of the spiracle fused to body wall, but with free distal edge . Physalaemus cuvieri

- Oral disc with labial teeth row P-3 not reduced, with almost the same length of the P-2; row of marginal papillae without ventral gap; nares length shorter than one-half the ocular diameter; centripetal wall of the spiracle totally fused to the body wall ....

20 Nares opening directed dorsally; internarial distance shorter than one ocular diameter; body ovoid in dorsal view and globular in lateral view ... Eupemphix nattereri

- Nares opening directed laterally; internarial distance longer than an ocular diameter; body oval in dorsal view and depressed in lateral view .............. Leptodactylus fuscus

21 Nares diameter shorter than one-third the ocular diameter; spiracle with opening directed ventrally; submarginal papillae absent ...... Physalaemus centralis

- Nares diameter longer than one-third the ocular diameter; spiracle with opening directed dorsally; submarginal papillae present

..Physalaemus fuscomaculatus

\section{Discussion}

The northwestern of São Paulo State is one of the most deforested regions from Brazil, as result of agricultural and pasture activities (PROBIO 1998). This condition restricts the majority of habitats available for anuran reproduction to temporary ponds and, together with the pronounced dry season, limits the occurrence of the majority of species to the rainy season (Figure 12). Among the tadpoles found in this region, five from 15 exotrophic ecomorphological guilds revised by McDiarmid \& Altig (1999) are represented: benthic, carnivorous, nektonic, macrophagous and suspension feeders (type 1) tadpoles (Table 1). In this manner, considering the extension of the sampled area, the severity of the dry season and the predominance of temporary ponds, the morphological diversity found among tadpoles can be considered great. Even under the influence of these restrictive conditions, the tadpoles explore the different types of available resources in the ponds, using different microhabitats or food resources, or presenting different feeding behaviors (Rossa-Feres et al. 2004). Despite the absence of historical records for the herpetofauna from this region, the occurrence of only five (Table 2) from 39 reproductive modes (Haddad \& Prado 2005) can be explained by climate severity and impacts due to extensive land use.

\section{Acknowledgements}

We thank Profs. Drs. R.J.F. Feres, S.P. de Carvalho-eSilva and L. Casatti by the critical review of the manuscript, F.A. Hernandes and A.A. Bispo for the computer software assistance, and R.T. Saito for initial incentive. Research support was provided by Fundação de Amparo à Pesquisa do Estado de São Paulo (FAPESP) grant 01/07944-7 (D.C.R.F.) and by Coordenação de Aperfeiçoamento de Pessoal de Nível Superior (CAPES) grant 3300415-3 (F.N.). All drawings by F.N. 


\section{References}

ALTIG, R. \& MCDIARMID, R.W. 1999a. Diversity: Familial and Generic Characterizations. In Tadpoles. The Biology of Anuran Larvae (R.W. McDiarmid \& R. Altig, eds.). University of Chicago Press, Chicago and London, p.295-337.

ALTIG, R. \& MCDIARMID, R.W. 1999b. Body Plan: Development and Morphology. In Tadpoles. The Biology of Anuran Larvae (R.W. McDiarmid, \& R. Altig, eds.). University of Chicago Press, Chicago and London, p.24-51.

ALVES, A.C.R. \& CARVALHO-E-SILVA, S.P. 1999. Descrição da larva de Scinax similis (Cochran) com notas comparativas sobre o grupo "ruber” no sudeste do Brasil (Amphibia, Anura, Hylidae). Rev. Bras. Zool. 16(2):507-512.

BARCHA, S.F. \& ARID, F.M. 1971. Estudo da evapotranspiração na região norte-ocidental do Estado de São Paulo. Rev. C. Fac. Ciênc. Let. 1:94-122.

BERNARDE, P.S. \& KOKUBUM, M.N.C. 1999. Anurofauna do município de Guararapes, Estado de São Paulo, Brasil (Amphibia: Anura). Acta Biol. Leopoldensia 21(1):89-97.

BOKERMANN, W.C.A. 1963. Girinos de anfíbios brasileiros I. (Amphibia: Salientia). Anais Acad. Bras. Ciência 35(3):465-474.

BOKERMANN, W.C.A. 1962. Sobre uma pequena coleção de anfíbios do Brasil Central, com a descrição de uma espécie nova de Physalaemus. Rev. Bras. Biol. 22(3):213-219.

BOKERMANN, W.C.A. \& SAZIMA, I. 1973. Anfíbios da Serra do Cipó, Minas Gerais, Brasil. 1 -Espécies novas de “Hyla” (Anura, Hylidae). Rev. Bras. Biol. 33(3):329-336.

BRANDÃO, R.A. \& ARAÚJO, A.F.B. 1998. Herpetofauna da estação ecológica de águas emendadas. In Vertebrados da Estação Ecológica de Águas Emendadas (J. Marinho-Filho, F. Rodrigues \& M. Guimarães, eds.). Governo do Distrito Federal, Brasília, p.9-18.

CAIS, A. 1992. Aspectos biológicos e status taxonômico de Hyla biobeba Bokermann \& Sazima, 1973 (Amphibia Anura). Tese de Doutorado, UNESP, Rio Claro.

CEI, J.M. 1980. Amphibians of Argentina. Monit. Zool. Ital. N.S.:1-609.

DE SÁ, R.O. 1995. Hyla albopunctata. Catal. Am. Amphib. Rept. 602:1-5.

DUELLMAN, W.E. 1970. The hylids frogs of Middle America. Monog. Mus. Nat. Hist. 1:1-753.

DUELLMAN, W.E. 1978. The biology of an Equatorial Herpetofauna in Amazonian Ecuador. Misc. Publ. 65:1-352.

DUELLMAN, W.E. 1997. Amphibians of La Escalera Region, southeastern Venezuela: Taxonomy, Ecology, and Biogeography. Scient. Papers. 2:1-52.
FAIVOVICH, J., HADDAD, C.F.B., GARCIA, P.C.A., FROST, D.R., CAMPBELL, J.A. \& WHEELER, W.C. 2005. Systematic review of the frog family Hylidae, with special reference to Hylinae: Phylogenetic analysis and taxonomic revision. Bull. Am. Mus. Nat. Hist. 294:1-240.

FERNANDEZ, K. \& FERNANDEZ, M. 1921. Algunos batracios argentinos. I. Cystignathidae. Imprenta y Casa editora "Coni”, Buenos Aires.

FROST, D.R. 2004. Amphibian Species of the World: an Online Reference. Version 3.0. American Museum of Natural History, New York, New York. http://research.amnh.org/ herpetology/amphibia (accessed 23 November 2004).

GOSNER, K.L. 1960. A simplified table for staging anuran embryos and larvae. Herpetol. 16:183-190.

GRIFFITHS, I. \& CARVALHO, A.L. 1965. On the validity of employing larval characters as major phyletic índices in Amphibia, Salientia. Rev. Bras. Biol. 25(2):115-121.

HADDAD, C.F.B. 1998. Biodiversidade dos anfíbios no Estado de São Paulo. In Biodiversidade do Estado de São Paulo, Brasil: síntese do conhecimento ao final do século XX. 6: Vertebrados (C.A. Joly \& C.E.M. Bicudo, org.). FAPESP, São Paulo, p. 15-26.

HADDAD, C.F.B. \& PRADO, C.P.A. 2005. Reproductive modes in frogs and their unexpected diversity in the Atlantic Forest of Brazil. Bioscience 55(3):207-217.

HADDAD, C.F.B. \& SAZIMA, I. 1992. Anfíbios anuros da Serra do Japi. In História Natural da Serra do Japi (L.P.C. Morellato, org.). Editora da UNICAMP/FAPESP, Campinas, v.3, p:188-211.

HEYER, W.R., RAND, A.S., CRUZ, C.A.G., PEIXOTO, O.L. \& NELSON, C.E. 1990. Frogs of Boracéia. Arq. Zool. 31(4):231-410.

KENNY, J.S. 1969. The amphibia of Trinidad. Stud. Fauna Cur. Carib. Is. 108(29):66-70.

LAVILLA, E.O. 1990. The tadpole of Hyla nana (Anura: Hylidae). J. Herpetol. 24(2):207-209.

LAVILLA, E.O. 1992. The tadpole of Dermatonotus muelleri (Anura: Microhylidae). Mus. Reg. Sci. Nat. Boll. 10(1):63-71.

LAVILLA, E.O. \& LANGONE, J.A. 1991. Ontogenic changes in spiracular and proctodeal tube orientation in Elachistocleis bicolor (Anura: Microhylidae). J. Herpetol. 25(1):119-121.

LAVILLA, E.O., VAIRA, M. \& FERRARI, L. 2003. A new species of Elachistocleis from the Andean Yungas of Argentina, with comments on the Elachistocleis ovalisE. bicolor controversy. Amphibia-Reptilia 24:269-284.

LESCURE, J. 1973. Contribution a l'étude des amphibians de Guyane Française. II. Leptodactylus fuscus (Schneider) observation écologiques et éthologiques. Annales Mus. Hist. Nat. Nice 1:91-100. 
LIPS, K.R. \& SAVAGE, J.M. 1996. Key to known Tadpoles (Amphibia: Anura) of Costa Rica. Stud. Neotrop. Fauna Envir. 31:17-26.

MCDIARMID, R.W. \&ALTIG, R. 1999. Research: Materials and Techniques. In Tadpoles. The Biology of Anuran Larvae (R.W. McDiarmid \& R. Altig, eds.). University of Chicago Press, Chicago and London, p.7-23.

MIRANDA-RIBEIRO, A. 1926. Notas para servirem ao estudo dos Gymnobatrachios (Anura) brasileiros. Arq. Mus. Nac. 27:201-305.

NASCIMENTO, L.B., CARAMASCHI, U. \& CRUZ, C.A.G. 2005. Taxonomic review of the species groups of the genus Physalaemus Fitzinger, 1826 with revalidation of the genera Engystomops Jiménez-de-La-Espada, 1872 and Eupemphix Steindachner, 1863 (Amphibia, Anura, Leptodactylidae). Arq. Mus. Nac. 63(2):297-320.

NOMURA, F., ROSSA-FERES, D.C. \& PRADO, V.H. 2003. The tadpole of Physalaemus fuscomaculatus (Anura: Leptodactylidae) with a description of internal oral morphology. Zootaxa 370:1-8.

ORTON, G.L. 1953. The systematics of vertebrate larvae. Syst. Zool. 2:63-75.

PROBIO. 1998. Áreas de domínio do cerrado no Estado de São Paulo. Imprensa Oficial, São Paulo.

RADA DE MARTINEZ, D. 1981. Renacuajos de algunos anfíbios de Clarines (Edo. Anzoategui, Venezuela). Mem. Soc. C. Nat. Salle 41(115):58-75.

ROSA, C.N. 1965. Sistemática e biologia de alguns girinos do Estado de São Paulo. Bol. PUC SP - Zool. 25:467-487.

ROSSA-FERES, D.C. \& JIM, J. (1993) Tadpole of Physalaemus centralis (Anura, Leptodactylidae). Copeia 2:566-569.

ROSSA-FERES, D.C. \& JIM, J. 2001. Similaridade no sítio de vocalização em uma comunidade de anfíbios anuros na região noroeste do Estado de São Paulo, Brasil. Rev. Bras. Zool. 18(2):439-454.

ROSSA-FERES, D.C.; JIM, J. \& FONSECA, M.G. 2004. Diets of tadpoles from a temporary pond in southeastern Brazil (Amphibia, Anura). Rev. Bras. Zool. 21(4):745-754.

VIZOTTO, L.D. 1967. Desenvolvimento de anuros da região norte-ocidental do Estado de São Paulo. Tipografia Rio Preto, São José do Rio Preto.
Title: Characterization and taxonomic key for tadpoles (Amphibia: Anura) from the northwestern region of São Paulo State, Brazil. ${ }^{1}$

Authors: Denise de Cerqueira Rossa-Feres \& Fausto Nomura

Biota Neotropica, Vol. 6 ( number 1): 2006

http://www.biotaneotropica.org.br/v6n1/pt/ abstract?identification-key+bn00706012006

Date Received 05/15/2005 - Revised 10/10/2005

Accepted 01/01/2006

ISSN 1676-0611 

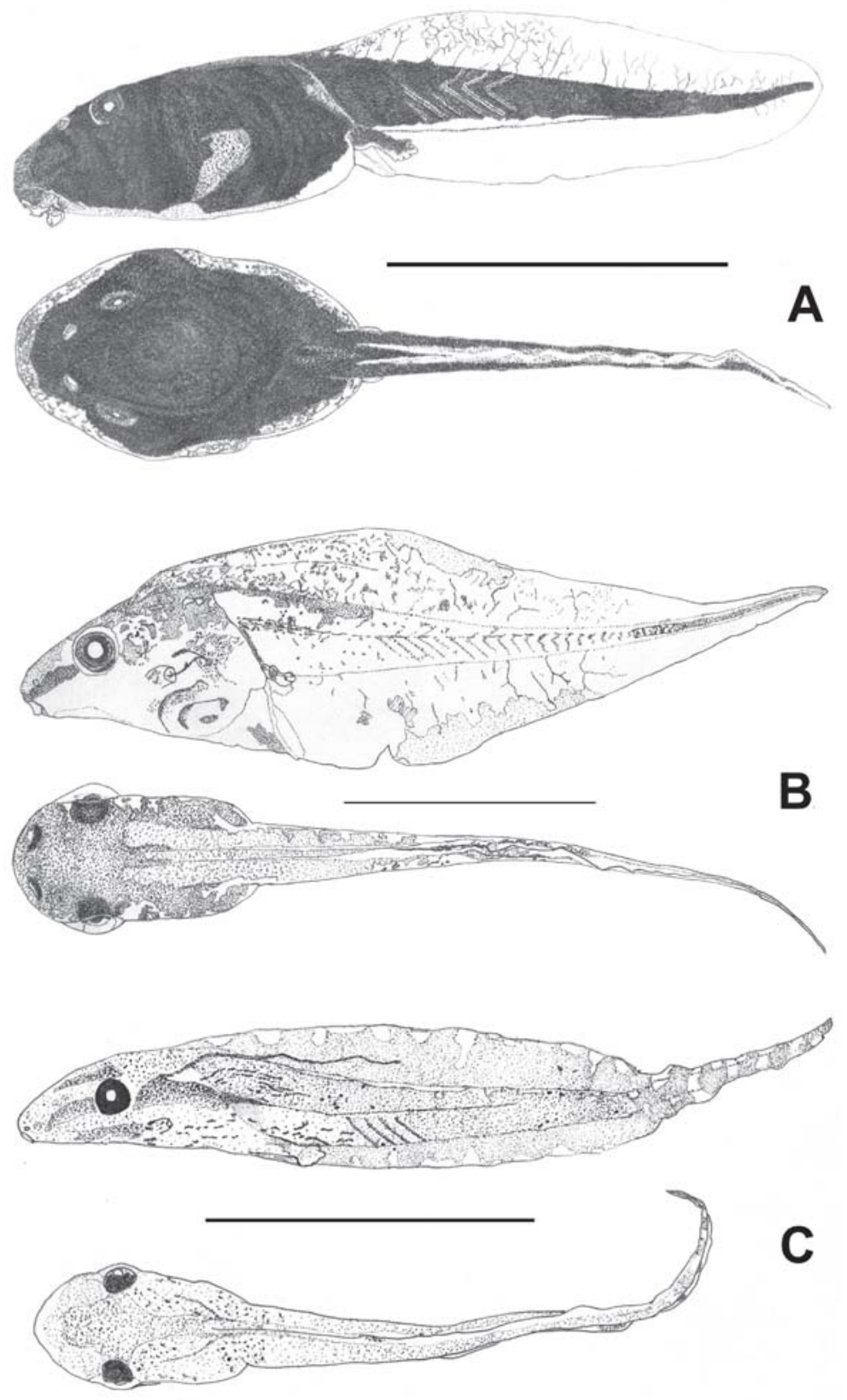

Figure 1. Tadpoles' lateral and dorsal view of: A) Bufo schneideri, B) Dendropsophus minutus, and C) D. nanus. Scale $=10 \mathrm{~mm}$. 

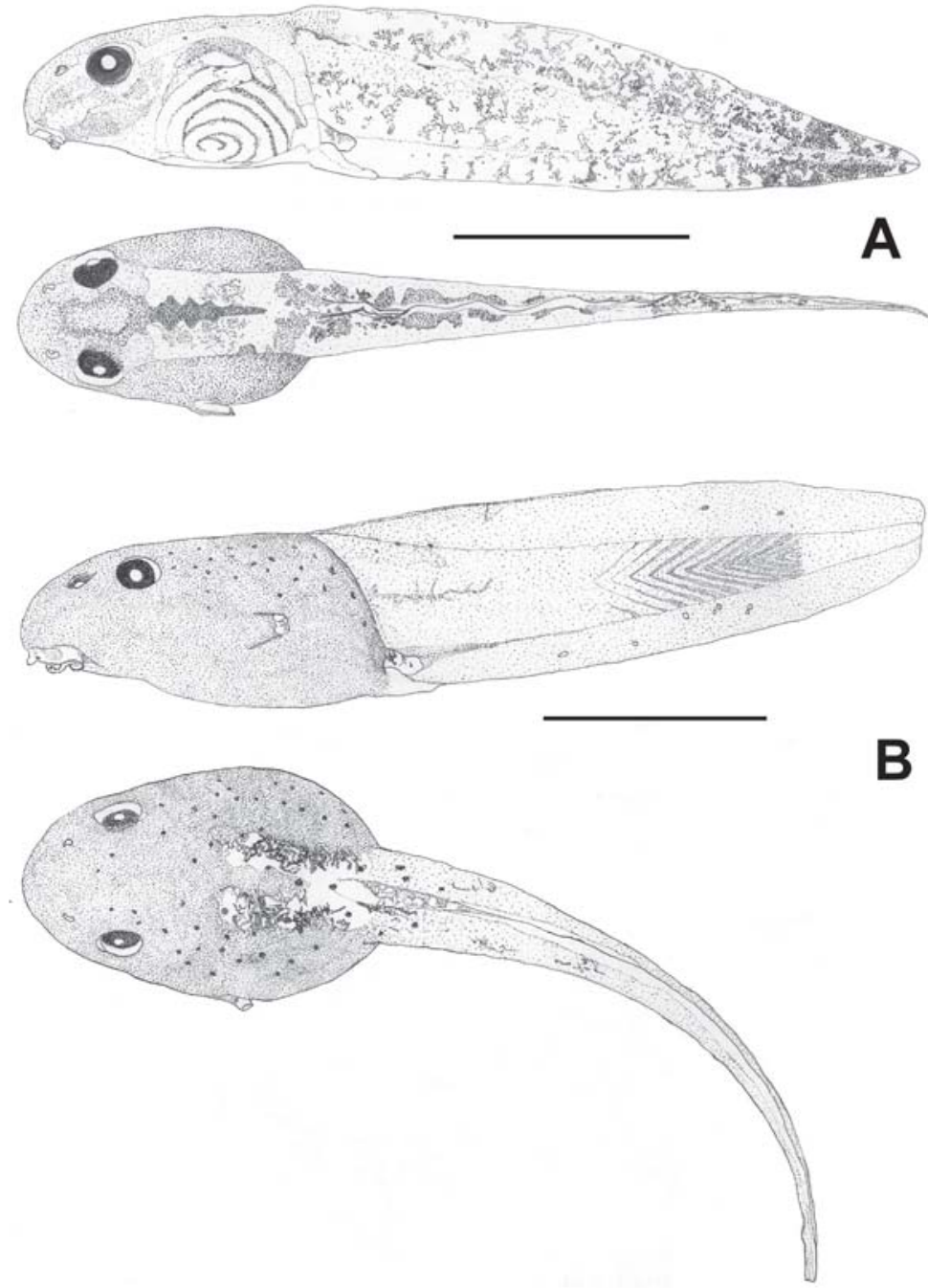

B
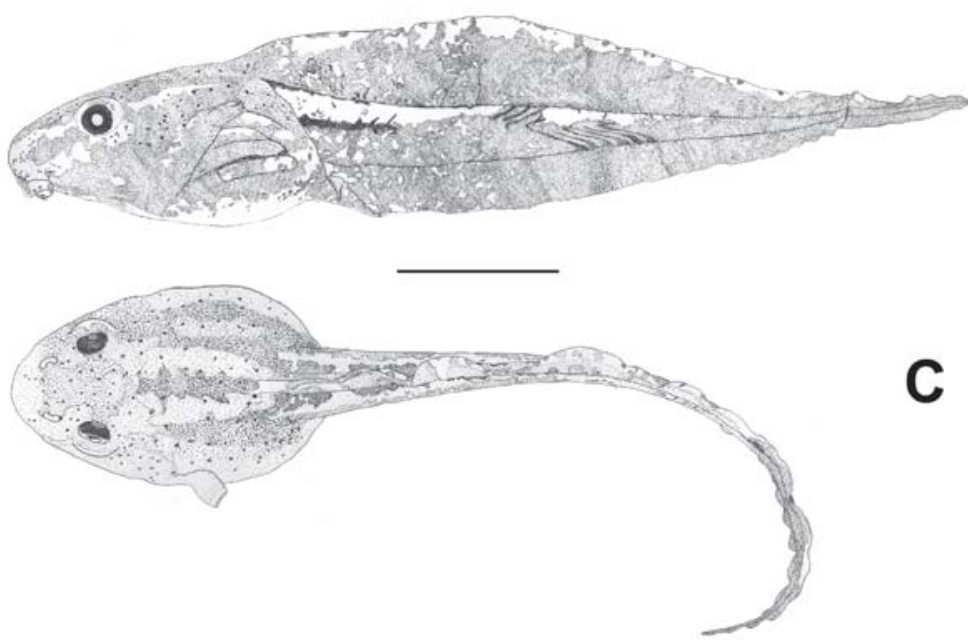

Figure 2. Tadpoles' lateral and dorsal view of: A) Hypsiboas albopunctatus, B) $\mathrm{H}$. lundii, and C) $\mathrm{H}$. raniceps. Scale $=10 \mathrm{~mm}$. 

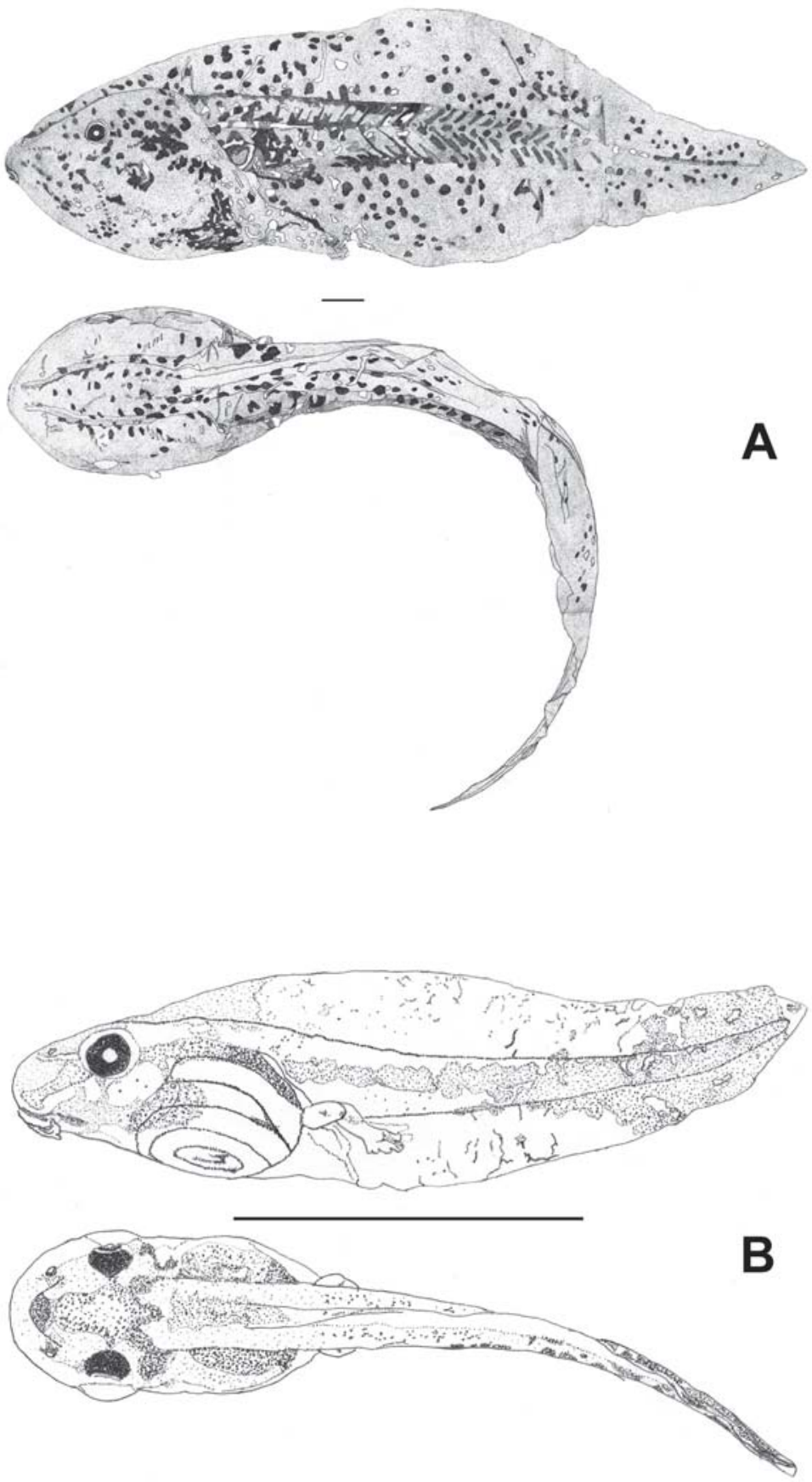

Figure 3. Tadpoles' lateral and dorsal view of: A) Pseudis paradoxa and B) Scinax fuscomarginatus. Scale $=10 \mathrm{~mm}$. 

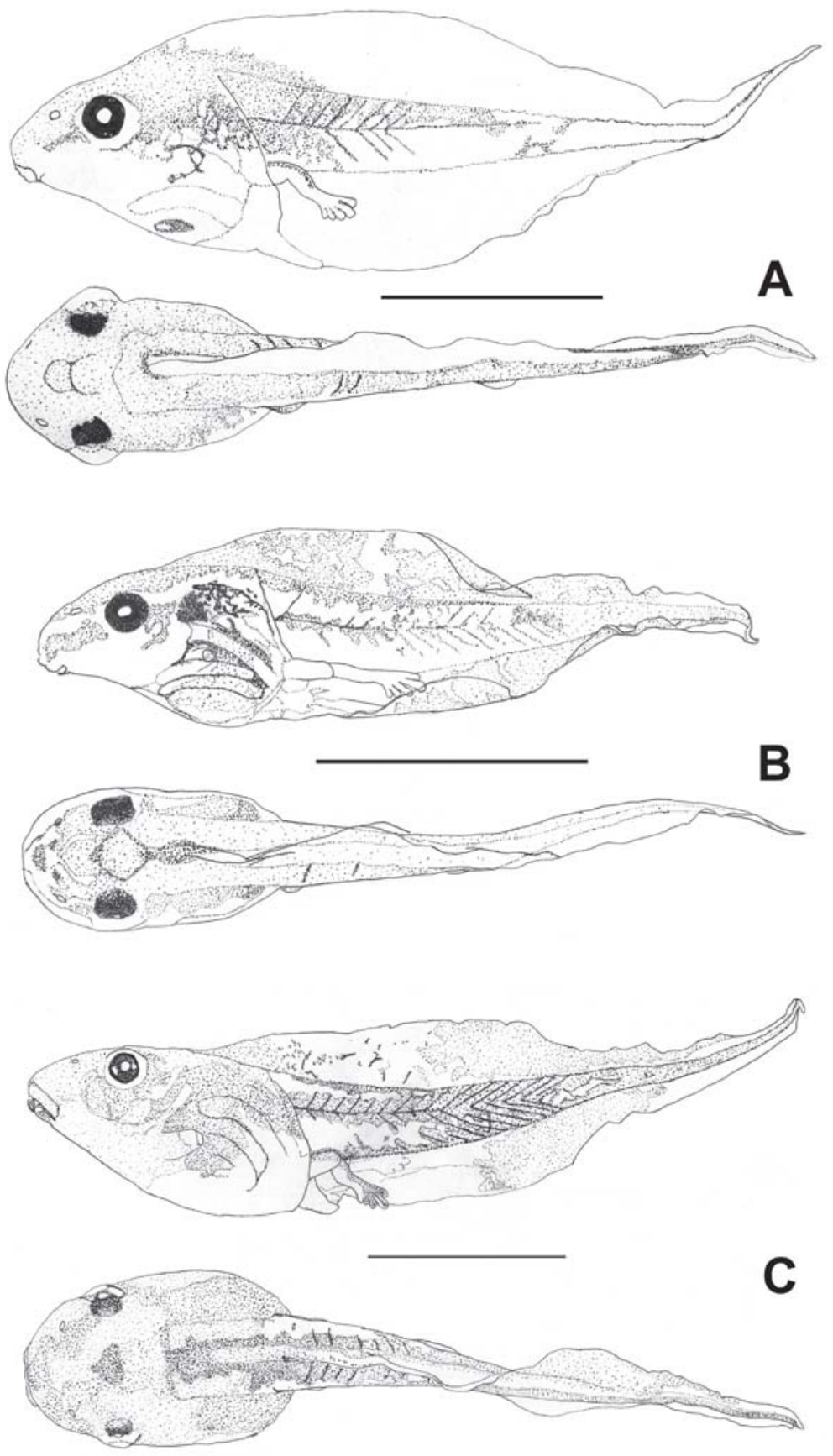

Figure 4. Tadpoles' lateral and dorsal view of: A) Scinax fuscovarius, B) S. similis, and C) Trachycephalus venulosus. Scale $=10 \mathrm{~mm}$. 

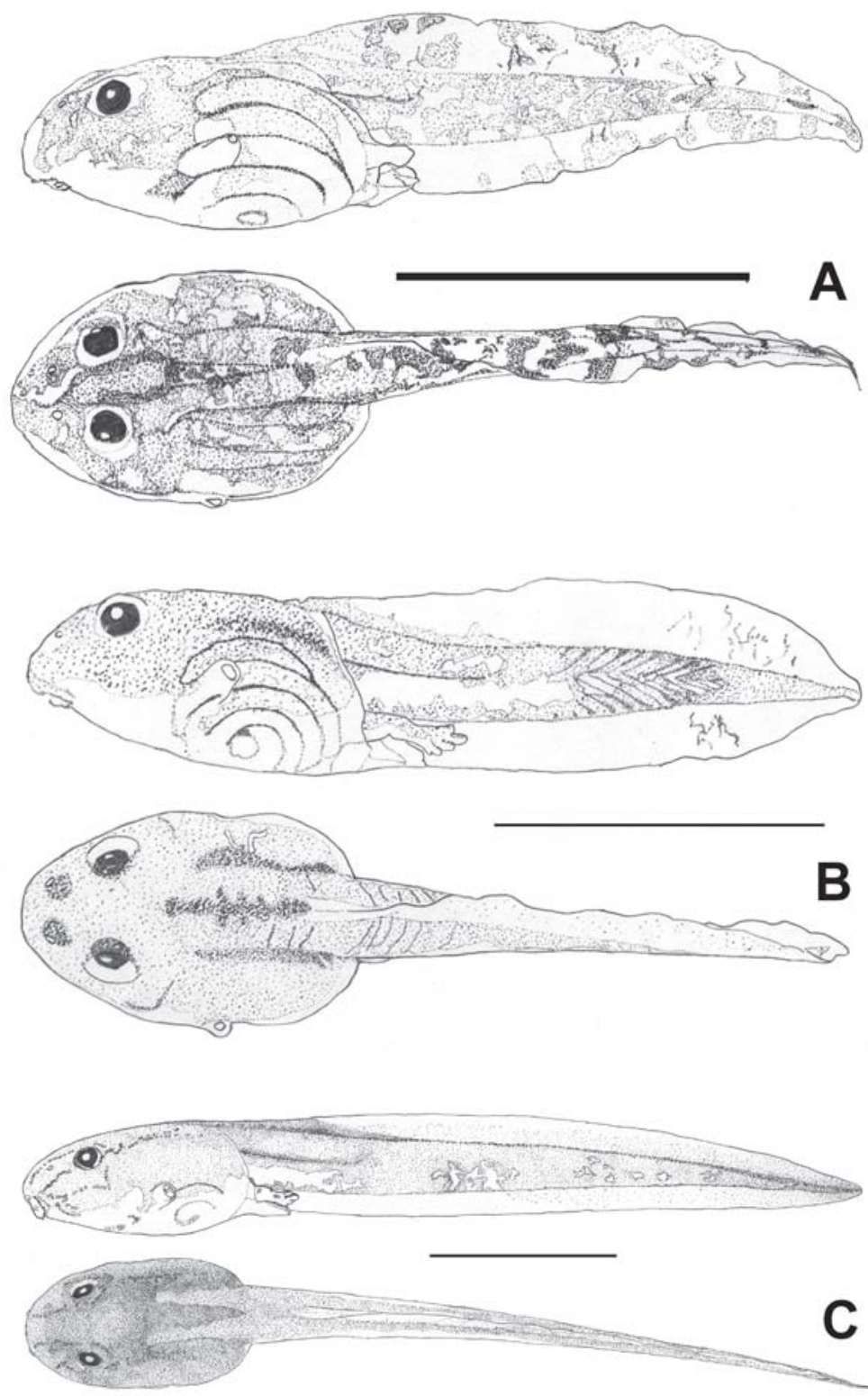

Figure 5. Tadpoles' lateral and dorsal view of: A) Eupemphix nattereri, B) Leptodactylus fuscus, and C) L. labyrinthicus. Scale $=10 \mathrm{~mm}$. 

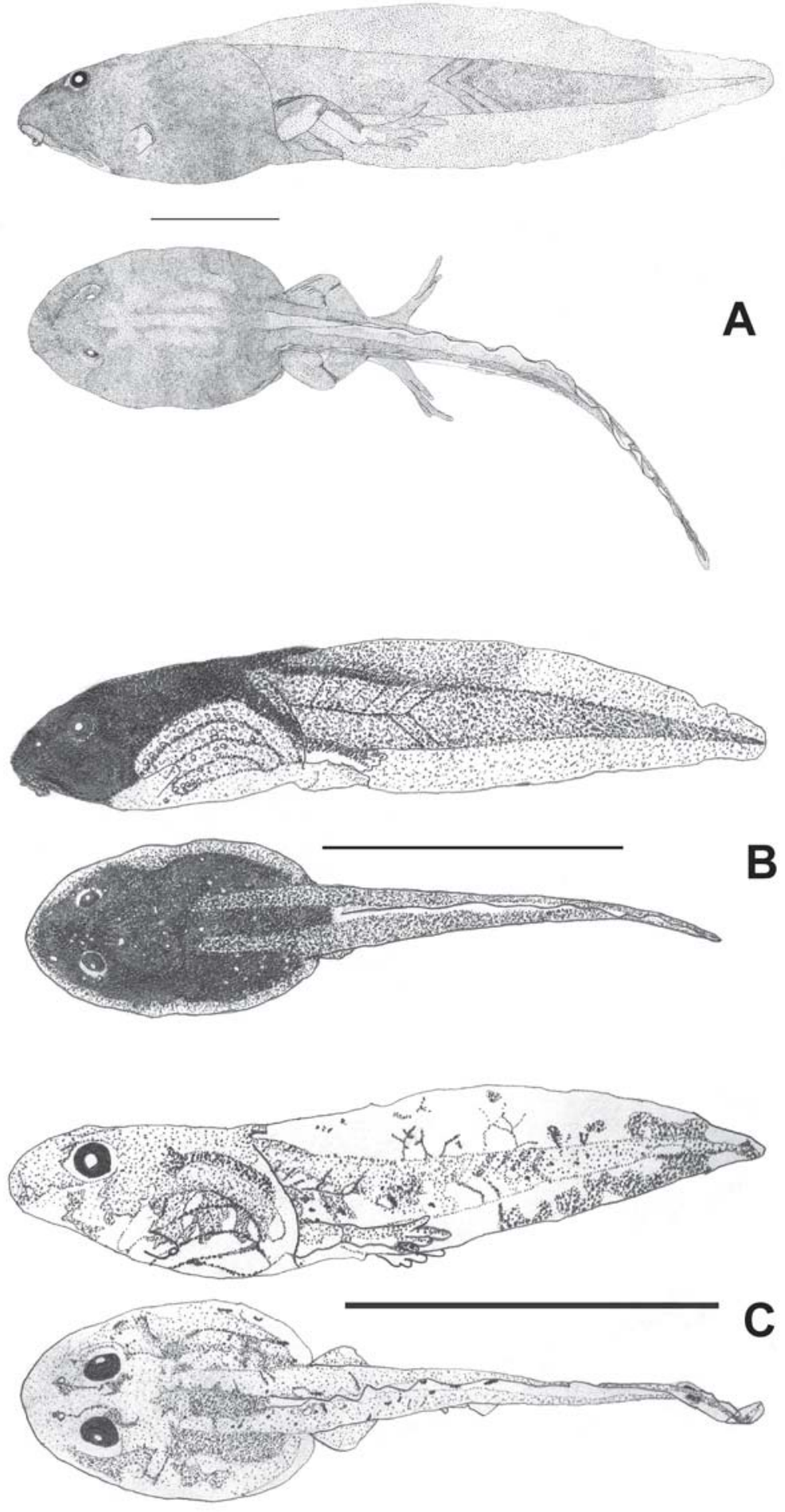

Figure 6. Tadpoles' lateral and dorsal view of: A) Leptodactylus ocellatus, B) L. podicipinus, and C) Physalaemus centralis. Scale $=10 \mathrm{~mm}$. 

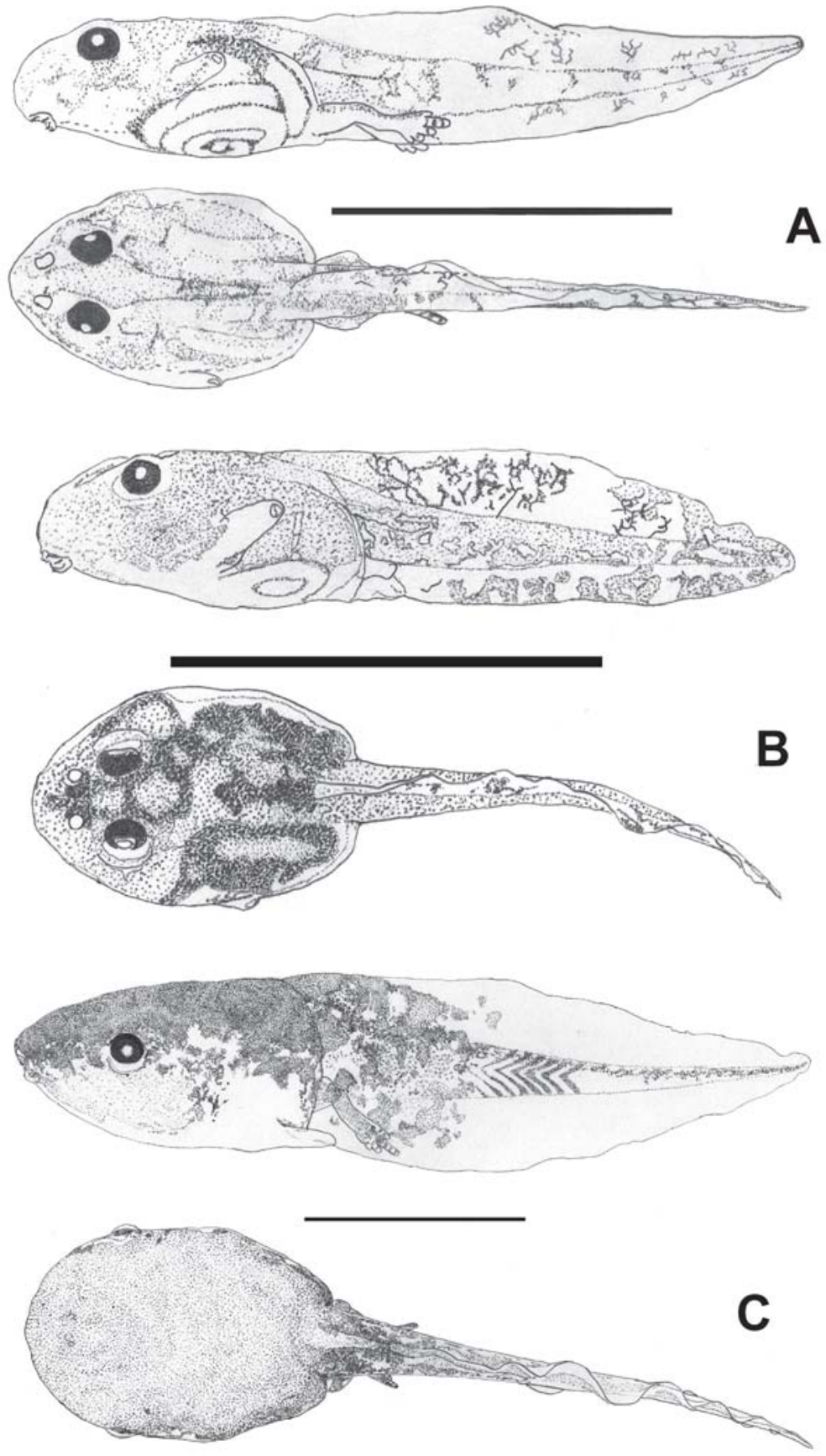

Figure 7. Tadpoles' lateral and dorsal view of: A) Physalaemus cuvieri, B) P. fuscomaculatus, and C) Dermatonotus muelleri. Scale $=10 \mathrm{~mm}$. 

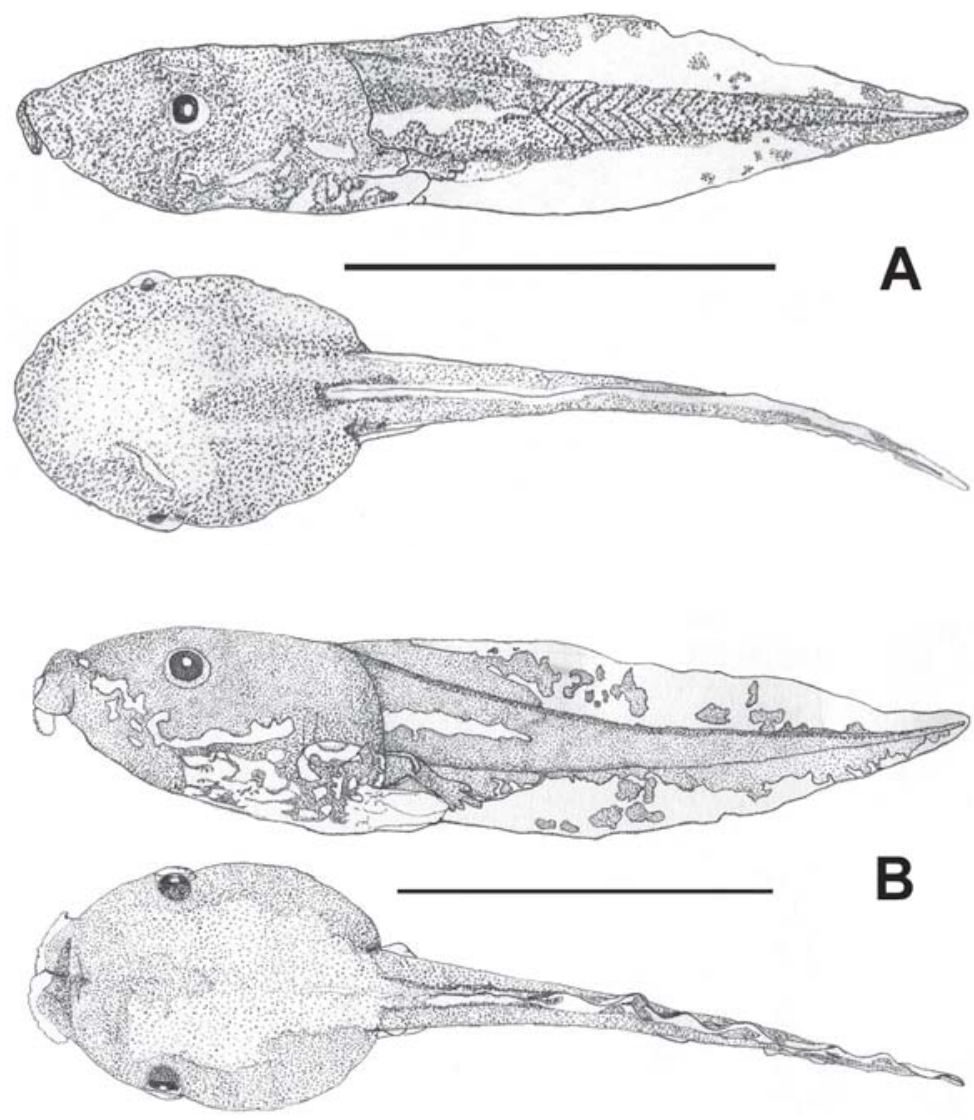

Figure 8. Tadpoles' lateral and dorsal view of: A) Elachistocleis bicolor, and B) Elachistocleis sp. Scale $=10 \mathrm{~mm}$. 
Rossa-Feres, D.C and Nomura,F. - Biota Neotropica, v6 (n1) - BN00706012006
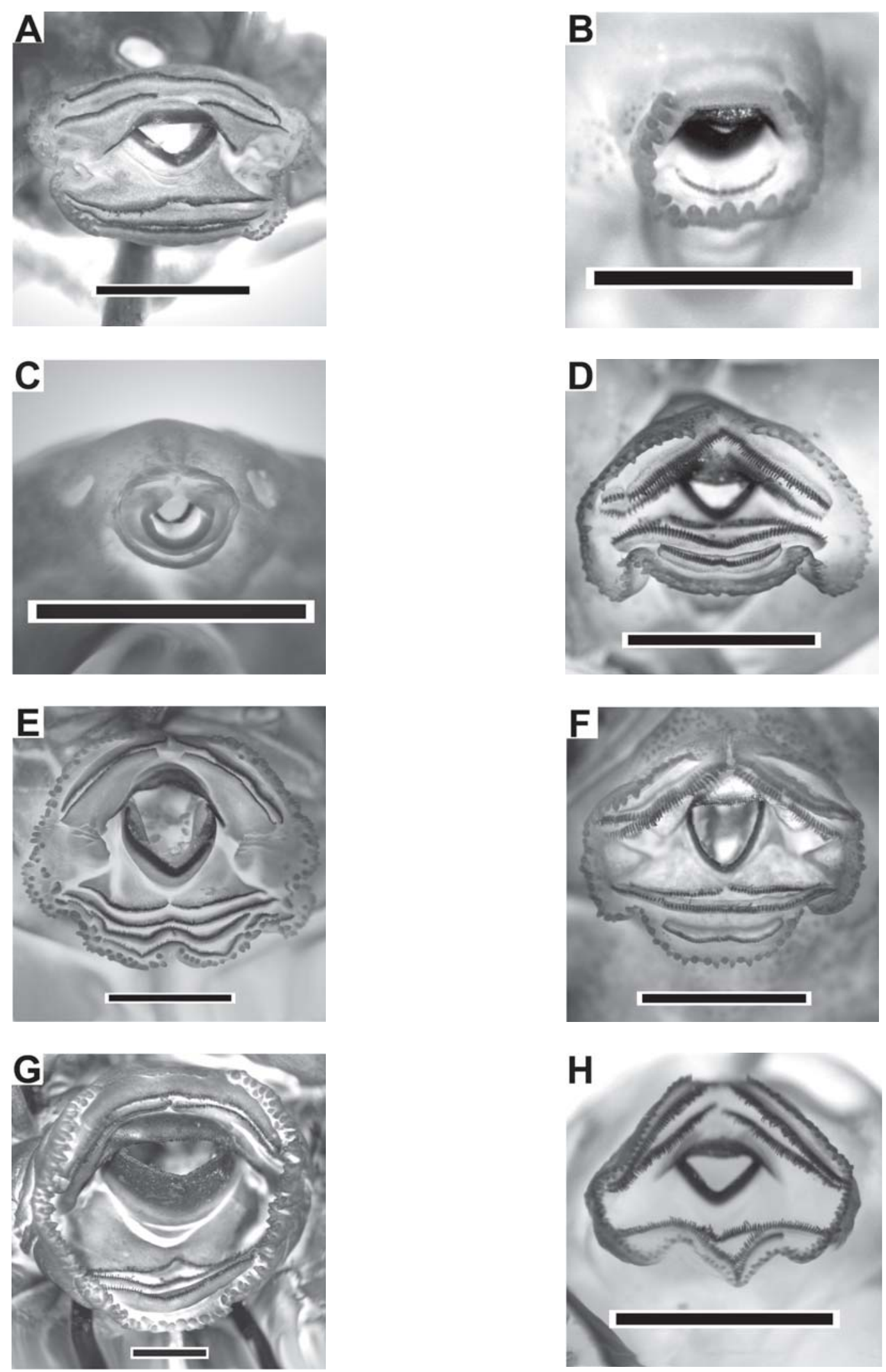

Figure 9. Tadpoles' oral apparatus of: A) Bufo schneideri, B) Dendropsophus minutus, C) D. nanus, D) Hypsiboas albopunctatus, E) H. lundii, F) $\mathrm{H}$. raniceps, G) Pseudis paradoxa, and H) Scinax fuscomarginatus. Scale $=1 \mathrm{~mm}$. 
Rossa-Feres, D.C and Nomura,F. - Biota Neotropica, v6 (n1) - BN00706012006
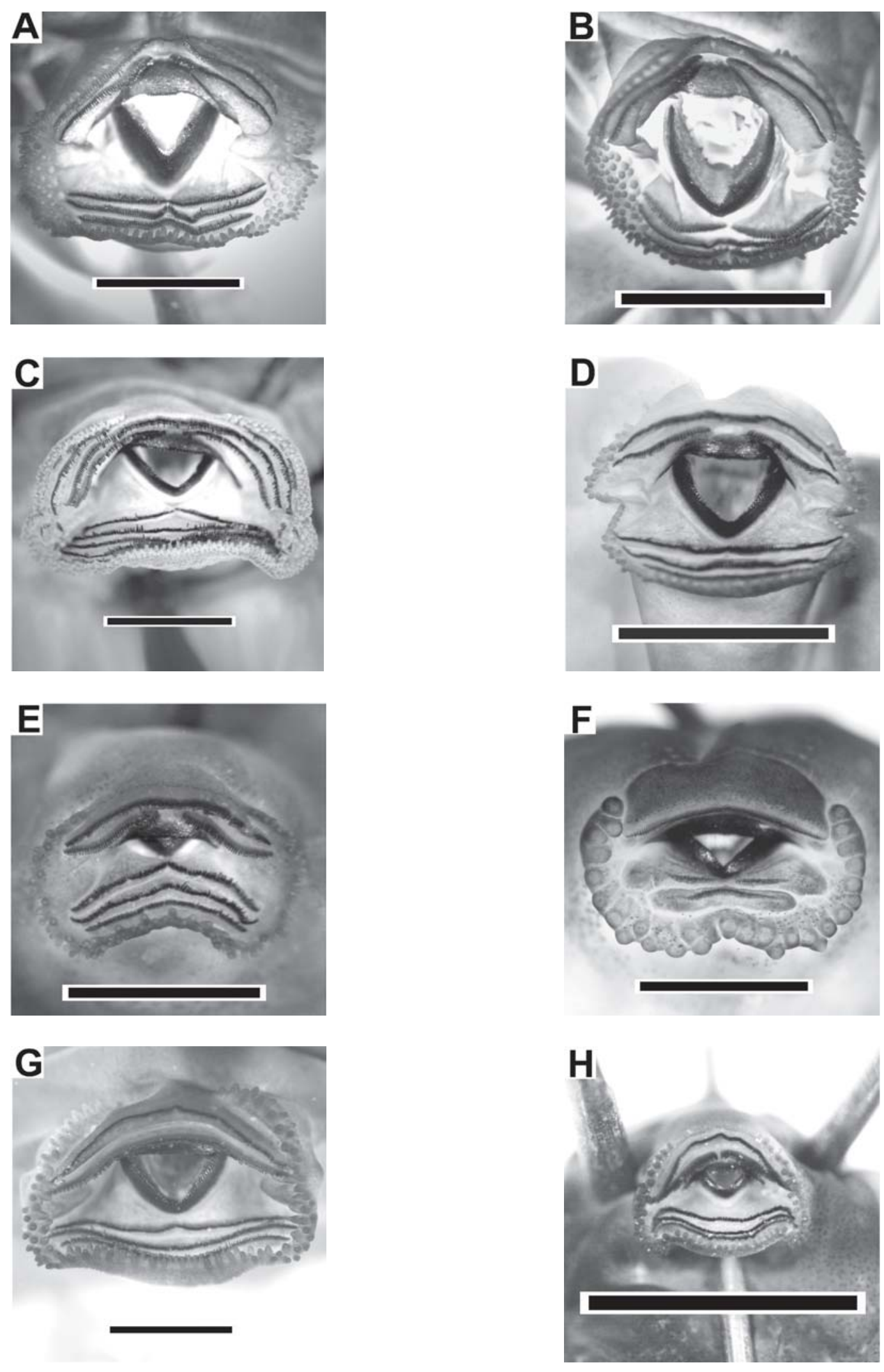

Figure 10. Tadpoles' oral apparatus of: A) S. fuscovarius, B) S. similis, C) Trachycephalus venulosus, D) Eupemphix nattereri, E) Leptodactylus fuscus, F) L. labyrinthicus, G) L. ocellatus and H) L. podicipinus. Scale $=1 \mathrm{~mm}$. 
Rossa-Feres, D.C and Nomura,F. - Biota Neotropica, v6 (n1) - BN00706012006
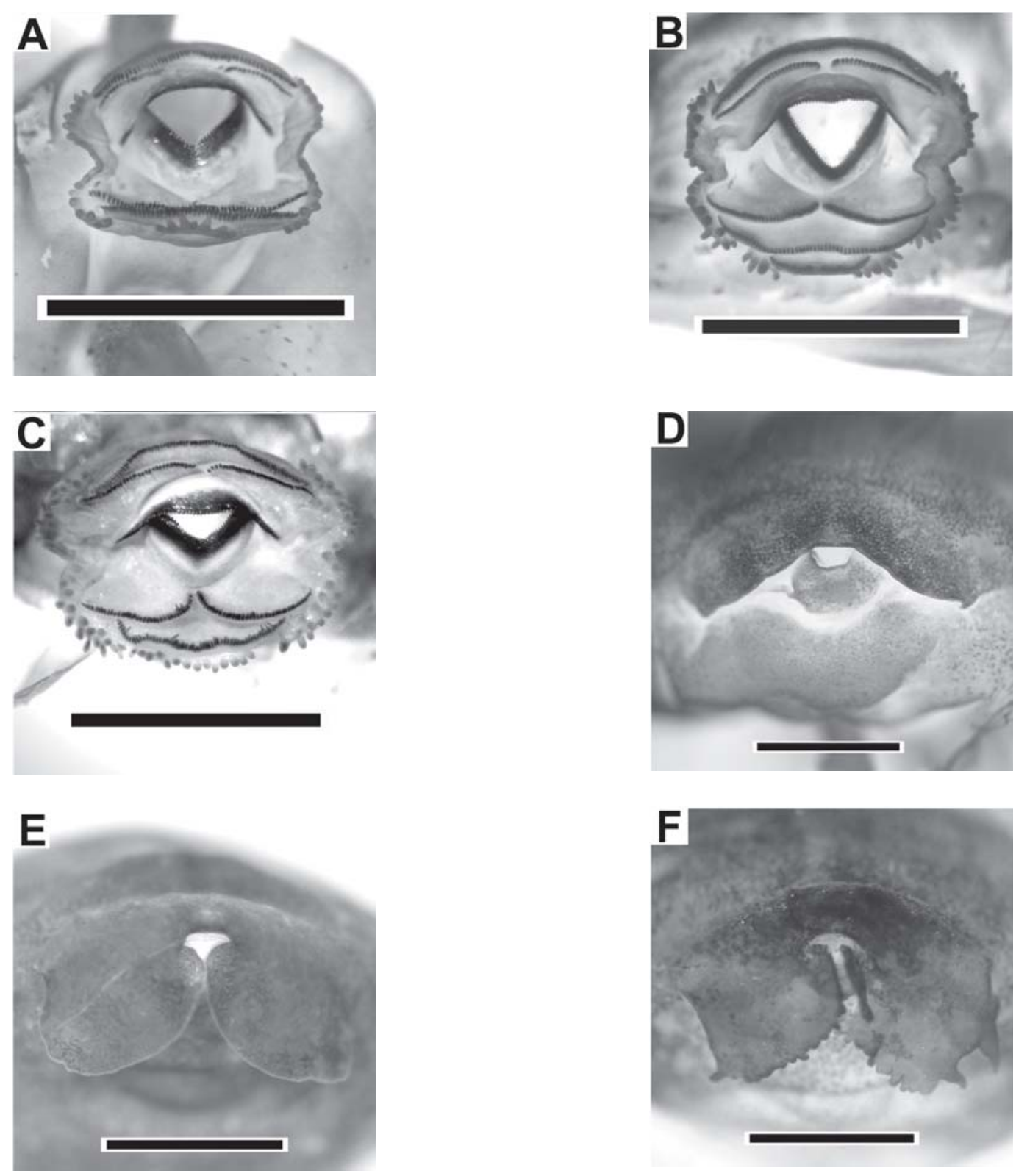

Figure 11. Tadpoles' oral apparatus of: A) Physalaemus centralis, B) P. cuvieri, C) P. fuscomaculatus, D) Dermatonotus muelleri, E) Elachistocleis bicolor, and F) Elachistocleis sp. Scale $=1 \mathrm{~mm}$. 


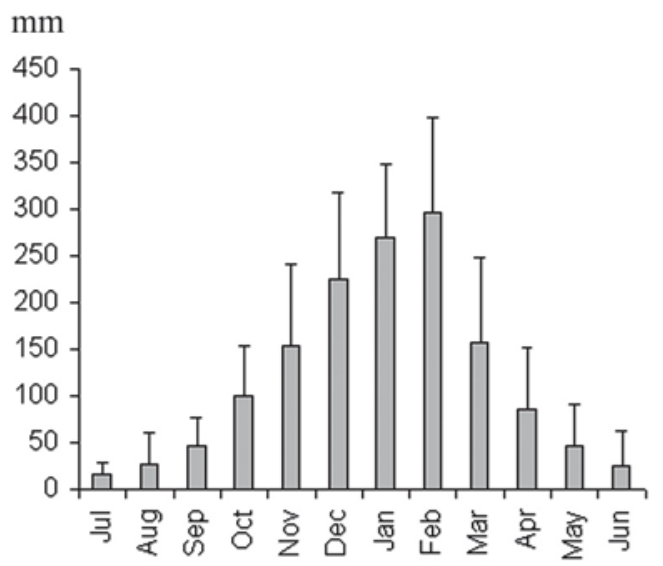

Bufo schneideri

Dendropsophus minutus

Dendropsophus nanus

Hypsiboas albopunctatus

Hypsiboas lundii

Hypsiboas raniceps

Pseudis paradoxa

Scinax fuscomarginatus

Scinax fuscovarius

Scinax similis

Trachycephalus venulosus

Eupemphix nattereri

Leptodactylus fuscus

Leptodactylus labyrinthicus

Leptodactylus ocellatus

Leptodactylus podicipinus

Physalaemus centralis

Physalaemus cuvieri

Physalaemus fuscomaculatus

Dermatonotus muelleri

Elachistocleis bicolor

Elachistocleis sp.

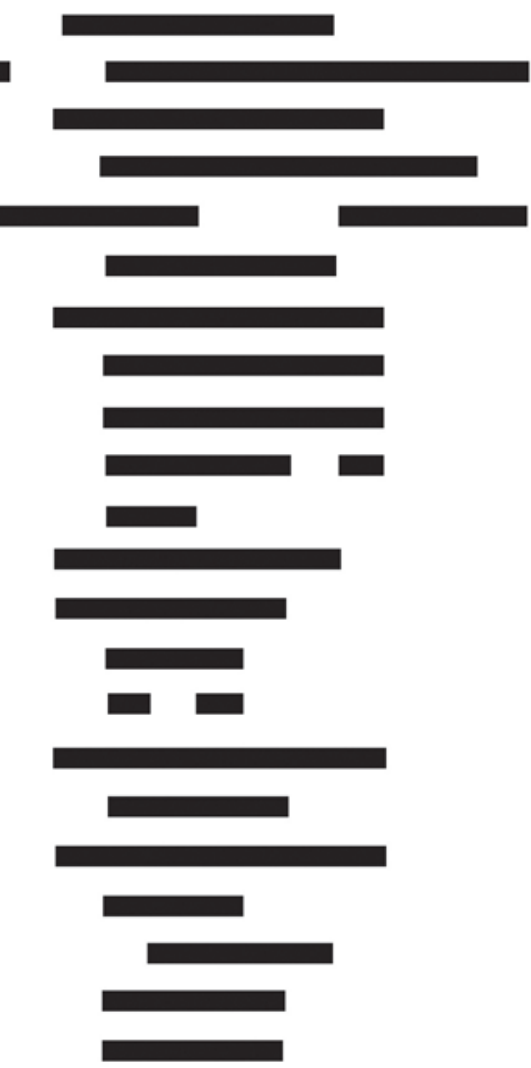

Figure 12. Temporal distribution of 22 anuran species from the northwestern region of São Paulo State, Brazil. The histogram represents mean pluviometric precipitation ( $n=11$ years) of three localities (Jales, Nova Aliança and São José do Rio Preto). Vertical bar = standard deviation. Source of pluviometric data: Embrapa Uva e Vinho (Jales) and Coordenadoria de Assistência Técnica Integral - CATI (São José do Rio Preto). Temporal distribution of Hypsiboas lundii according to Cais (1992). 
Table 1. Ecomorphological guilds, according McDiarmid \& Altig (1999), recorded for 22 known tadpoles from northwestern region of São Paulo state, Brazil. *according Rossa-Feres et al. (2004).

\begin{tabular}{ll}
\hline Ecomorphological guild & Species \\
\hline Benthic & Hypsiboas albopunctatus \\
& H. lundii \\
& H. raniceps \\
& Eupemphix nattereri \\
& Leptodactylus fuscus \\
& L. ocellatus \\
& L. podicipinus \\
& Physalaemus centralis \\
& P. cuvieri \\
& P. fuscomaculatus \\
& Dendropsophus minutus \\
& Pseudis paradoxa \\
Nektonic & Scinax fuscomarginatus \\
& S. fuscovarius \\
& S. similis \\
& Trachycephalus venulosus \\
& Leptodactylus labyrinthicus \\
Carnivorous & Dendropsophus nanus \\
Macrophagous & Dermatonotus muelleri \\
Suspension feeder (Type 1) & Elachistocleis bicolor \\
& Elachistocleis sp. \\
Benthic and neustonic* & Bufo schneideri \\
\hline
\end{tabular}

Table 2. Reproductive modes recorded for anurans from northwestern region of São Paulo State, Brazil (according Haddad \& Prado, 2002).

\begin{tabular}{|c|c|c|}
\hline Mode & Family & Species in the region \\
\hline \multicolumn{3}{|l|}{ AQUATICS EGGS } \\
\hline \multicolumn{3}{|l|}{ Eggs deposited in water } \\
\hline \multirow{13}{*}{$\begin{array}{l}\text { Mode 1: Eggs and exotrophic tadpoles in lentic } \\
\text { water. }\end{array}$} & Hylidae & Dendropsophus minutus \\
\hline & & D. nanus \\
\hline & & Hypsiboas albopunctatus \\
\hline & & H. raniceps \\
\hline & & Pseudis paradoxa \\
\hline & & Scinax fuscomarginatus \\
\hline & & Scinax fuscovarius \\
\hline & & Scinax similis \\
\hline & & Trachycephalus venulosus \\
\hline & & Dermatonotus muelleri \\
\hline & Microhylidae & Elachistocleis bicolor \\
\hline & & Elachistocleis sp. \\
\hline & Bufonidae & Bufo schneideri \\
\hline $\begin{array}{l}\text { Mode 4: Eggs and hatchlings in constructed } \\
\text { basins. }\end{array}$ & Hylidae & Hypsiboas lundii \\
\hline \multicolumn{3}{|l|}{ Eggs in foam nests (aquatic). } \\
\hline \multirow{5}{*}{$\begin{array}{l}\text { Mode 11: Foam nests on pond; exotrophic } \\
\text { tadpoles in pond. }\end{array}$} & Leptodactylidae & Eupemphix nattereri \\
\hline & & Leptodactylus ocellatus \\
\hline & & Physalaemus centralis \\
\hline & & Physalaemus cuvieri \\
\hline & & Physalaemus fuscomaculatus \\
\hline Mode 13: Foam nest in water-filled basins & Leptodactylidae & Leptodactylus labyrinthicus \\
\hline adjacent to water. & & L. podicipinus \\
\hline \multicolumn{3}{|l|}{ TERRESTRIAL OR ARBOREAL EGGS } \\
\hline \multicolumn{3}{|l|}{ Eggs on ground, on rocks, or in burrows } \\
\hline $\begin{array}{l}\text { Mode 17: Eggs and hatchlings in excavated } \\
\text { nests; exotrophic tadpoles in ponds. }\end{array}$ & Leptodactylidae & Leptodactylus fuscus \\
\hline
\end{tabular}

http://www.biotaneotropica.org.br 